Financialisation and real investment in the European Union using a country-level analysis: beneficial or prejudicial effects?

Ricardo Barradas

Dezembro de 2015

WP n. ${ }^{\circ} 2015 / 10$

DOCUMENTO DE TRABALHO

WORKING PAPER

DINAMIR'CET

CENTRO DE ESTUDOS SOBRE A MUDANCÁ
SOCIOECONÓMICA E O TERRITOHIO

ISCTE-IUL 


\section{DINAMIR'CET}

CENTRO DE ESTUDOS SOBRE A MUDANCY
SOCIOECONOMICA E TERAITÓRIO

ISCTE-IUL

Financialisation and real investment in the European Union using a country-level analysis: beneficial or prejudicial effects?

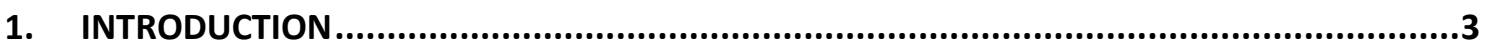

2. THE RELATIONSHIP BETWEEN FINANCIALISATION AND REAL INVESTMENT ...................5

3. FINANCIALISATION AND REAL INVESTMENT: AN ECONOMIC MODELISATION ..............10

4. DATA AND METHODOLOGY: THE ECONOMETRIC FRAMEWORK ...............................14

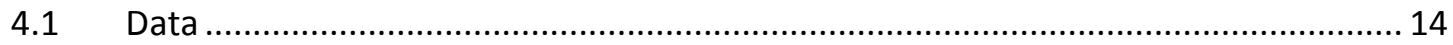

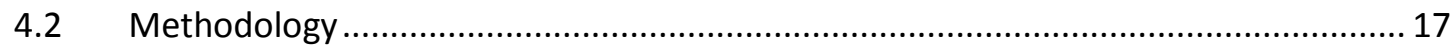

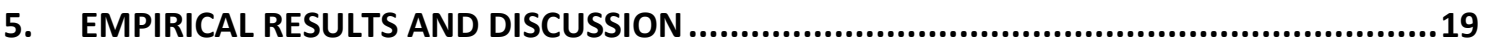

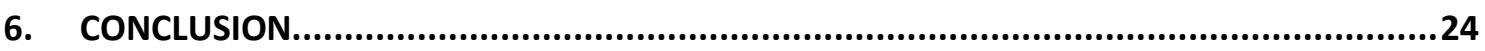

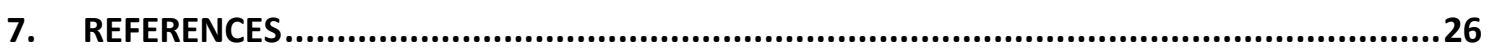

8. APPENDIX

* rbarradas@escs.ipl.pt / rpbarradas@iscal.ipl.pt; DINÂMIA'CET - IUL and Instituto Universitário de Lisboa (ISCTE-IUL); Higher School of Communication and Media Studies (Polytechnic Institute of Lisbon) Higher Institute of Accounting and Administration of Lisbon (Polytechnic Institute of Lisbon) 


\title{
Financialisation and real investment in the European Union using a country-level analysis: beneficial or prejudicial effects? ${ }^{1}$
}

\begin{abstract}
This paper makes an empirical assessment of the relationship between financialisation and real investment by non-financial corporations using panel data composed of 27 European Union countries over 19 years (from 1995 to 2013). On one hand, financialisation leads to a rise in financial investments, deviating funds from real investments ("crowding out" effect). On the other, pressures from shareholders to intensify financial payments restrict the funds available for new real investments. We estimate an aggregate investment equation with the traditional variables (profitability, debt, cost of capital, savings rate and output growth) and two further measures of financialisation (financial receipts and financial payments). Findings show that financialisation has damaged real investment in European Union countries, mainly through the channel of financial payments either in interest or dividend payments. It is also found that the prejudicial effects of financialisation in investment are more marked in more financialised countries. In addition, it is concluded that debt has a harmful effect on real investment as the increasing levels of non-financial corporations' indebtedness prevent the use of new debts to finance real investments.
\end{abstract}

\section{KEYWORDS}

Financialisation, Investment, The European Union, Panel Data, Driscoll and Kraay Estimator

\section{JEL CLASSIFICATION}

C23, D20, E22 and E44

\footnotetext{
1 The author is grateful for the helpful comments and suggestions from an anonymous referee, Luís Martins, Marta Silva, Ricardo Correia, Sérgio Lagoa and Sofia Vale. The usual disclaimer applies. 


\section{INTRODUCTION}

Conventional economic theory finds that the growth of finance fosters economic growth due to the positive association between savings and investments (e. g. Levine, 2005). Nevertheless, scholars of financialisation (Orhangazi, 2008a and 2008b; Hein and van Treeck, 2010; Hein, 2012; Hein and Dodig, 2015; among others) postulates that the increasing growth of finance harms the real investment of non-financial corporations (NFCs) through two channels. The first channel involves the NFCs' greater engagement in financial activities, which tends to divert funds from real investments ("crowding out" effect). The second is caused by the strong pressures on NFCs to increase their financial payments (interest, dividends and/or stocks buybacks) to the financial markets and respective shareholders, which leads to lower retention ratios and fewer funds for long-term productive projects.

In light of this, some empirical studies have been conducted in recent years to assess the relationship between financialisation and real investment. Most of these derive and estimate investment equations that find statistical evidence of the prejudicial effects of the phenomenon on real investment (e.g. Stockhammer, 2004; Orhangazi, 2008a and 2008b; van Treeck, 2008; Onaran et al., 2011; Barradas and Lagoa, 2014).

This paper examines the impact of financialisation on the real investment of NFCs in European Union (EU) countries between 1995 and 2013, contributing to the literature in two ways. First, it focuses on EU countries, whereas most studies are oriented to the specificities of large, highly developed and financialised countries like the USA or the UK. Second, a panel data econometric analysis is used rather than the time series econometric analysis more usual in empirical studies on this matter. This allows us to understand whether the prejudicial effects of financialisation have been generalised and transversal to a large set of countries or, alternatively, specific to certain countries. The use of a panel data econometric analysis also permits a larger number of observations and sample variability and thus improves the accuracy of estimates.

EU countries represent an interesting case study as they share common economic rules because they belong to the same economic and political region. However, these countries have some diversity in terms of financialisation due to their different types of financial system ("bank-based" or "market based" in the typology of Sawyer (2013)) and distinct growth models in the era of financialisation ("debt-led consumption boom", "domestic demand-led" and "export-led mercantilist" in the classification of Hein (2012)). These dissimilarities could

DINÂMIA'CET - IUL, Centro de Estudos sobre a Mudança Socioeconómica e o Território ISCTE-IUL - Av. das Forças Armadas, 1649-026 Lisboa, PORTUGAL 
explain the differences in the countries' levels of financialisation (Table A5 and Table A6 in Appendix). Despite this heterogeneity, there has been a downward trend in the investment rate in most of these countries (Figure A1 in Appendix), simultaneously with a rise in financial receipts and financial payments (Figure A7 and Figure A8 in Appendix). It is therefore interesting to determine whether there is a disruptive relationship between financialisation and real investment.

Accordingly, we estimate an investment equation using standard variables (profitability, debt, cost of capital, savings rate and the output growth) and two additional variables linked to financialisation (financial receipts and financial payments). We estimate an aggregate investment function given our interest in studying a macroeconomic issue.

It is concluded that financialisation exerts a negative influence on the real investment of EU countries, mainly through the second channel (either interest or dividends payments). This confirms our suspicion that the disruptive relationship between financialisation and real investment is a generalised phenomenon with a negative effect on EU countries from a macroeconomic point of view. However, we also conclude that the harmful effects of financialisation on real investment are greater in more financialised countries than in less financialised ones. It is also found that debt has a negative influence on real investment, which indicates that the higher debt levels of NFCs prevent them from obtaining new debts to finance productive investments.

The remainder of the paper is organised as follows. In Section 2, we give an overview of the theoretical and empirical literature on the relationship between financialisation and real investment of NFCs. An investment equation is built in Section 3. The data and the econometric methodology are described in Section 4. Section 5 presents the main findings and the respective discussion. Finally, Section 6 concludes.

DINÂMIA'CET - IUL, Centro de Estudos sobre a Mudança Socioeconómica e o Território ISCTE-IUL - Av. das Forças Armadas, 1649-026 Lisboa, PORTUGAL 


\section{THE RELATIONSHIP BETWEEN FINANCIALISATION AND REAL INVESTMENT}

It is generally accepted that higher rates of physical capital accumulation are crucial to sustain more dynamic economic growth and employment creation. Conventional economic theory advocates that the growth of finance is generally a positive phenomenon that supports the real investments of NFCs given the linkage between savings and investments. This idea has been reinforced by some empirical studies, which find a positive relationship between the growth of finance and economic growth (Levine, 2005; Ang, 2008; Arestis et al., 2015).

Nonetheless and according to the literature on financialisation, the growth of finance can be prejudicial to the real investments of NFCs through two distinct channels and it is theoretically discussed by Orhangazi (2008a and 2008b), Hein and van Treeck (2010), Hein (2012), Hein and Dodig (2015), among others. Figure 1 exhibits the channels (and factors that contribute to feed each of them) associated to the effects of financialisation on real investment.

Figure 1 - The channels associated to the prejudicial effects of financialisation on real investment

\begin{tabular}{l|l|l} 
& $\begin{array}{l}\text { Shorter planning horizons } \\
\text { More concerns about profits } \\
\text { Falling profits in the real sector } \\
\text { Involvement in financial activities } \\
\text { (more financial receipts) } \\
\text { Increasing external funding costs } \\
\text { Macroeconomic uncertainty } \\
\text { Changes in corporate governance } \\
\text { Mimetic behaviour } \\
\text { Institutional transmission }\end{array}$ \\
& $\begin{array}{ll}\text { High levels of indebtedness } \\
\text { Profit-based remunerations } \\
\text { Importance of institutional investors } \\
\text { "Shareholder value orientation" }\end{array}$
\end{tabular}

Source: Authors' representation based on Orhangazi (2008a and 2008b), Hein and van Treeck (2010), Hein (2012), Hein and Dodig (2015), among others

The first channel involves NFCs' increasing investments in financial activities and financial assets, which takes funds from real and productive activities. This is labelled by Hein (2012) and Hein and Dodig (2015) as the "management's preference channel". As both external and internal funds are limited, NFCs can only use these funds to invest in financial or real activities, since financial investments and real investments are considered perfect substitutes (Tobin, 1965). Thus, NFCs have fewer funds for real and productive investments when they increase 
their financial investments, and this is commonly referred to as the "crowding out effect" on real investment.

Krippner (2005) confirms that NFCs in the USA have increased their involvement in financial investments, as revealed by the growing importance of financial revenues and profits vis-à-vis the revenues and profits from real investments. Similarly, Cingolani (2013) argues that this behaviour expresses a higher accumulation of financial rents to the detriment of productive accumulation. The literature on financialisation offers several explanations to describe this stance by NFCs.

Firstly, Crotty (2005) advocates that the rise in financial investments (normally in the form of buying financial subsidiaries or expanding an already existing one) has been determined by NFCs' shorter planning horizons that are incompatible with the pursuit of long-term real projects. This short-termism mirrors a tendency among investors to sacrifice long-term investment projects in order to increase short-term profits (Aspara et al., 2014). According to Samuel (2000), this focus on short-term profits instead of long-term expansion reflects a certain "managerial myopia".

Secondly, Crotty (1990) concludes that shareholders are more concerned about current profitability than long-term expansion or, ultimately, the corporations' actual survival. Orhangazi (2008a and 2008b) stresses the strong pressures (essentially exerted by shareholders) on managers to achieve higher short-term returns. These pressures encourage financial investments, which tend to produce larger and more speculative short-term profits rather than real investments that normally involve more uncertainty and only produce profits in the medium and long-term. This is the so-called "rent-seeking behaviour" of NFCs. In fact, Hein (2012) and Hein and Dodig (2015) stress that NFCs face a "growth-profit trade-off" because shareholders' orientations are mainly for short-term profitability. Once again, this discourages the implementation of real capital projects. Baud and Durand (2012) also state that NFCs intensify their financial investments during bull markets which produce higher levels of profits and respond to the pressures of shareholders. Levy-Orlik (2012) notes that NFCs sometimes repurchase their own shares in order to prevent hostile takeovers, which also leads to a rise in share prices and increases short-term profits. Tomaskovic-Devey et al. (2015) even stress that managers' performance is no longer evaluated on market share but on their ability to generate short-term profits and increased share prices.

Thirdly, Crotty (2005) and Orhangazi (2008a and 2008b) argue that NFCs may be engaging more in financial activities in reaction to the downward trend of profits from the real sector and the increase in external funding costs since the 1980s. Baud and Durand (2012) 
confirm that US retailers' involvement in financial activities is the result of the decline of profitable opportunities in real investments, motivated by the maturation of markets, low profitability rates, stricter regulations, sluggish consumer demand and increasing competition. Soener (2015) notes that this is the political economy perspective in which NFCs are becoming more financialised so as to remain viable. Crotty (2005) terms this the "neoliberal paradox"; he claims that shareholders tend to coerce NFCs to remain competitive and profitable even in downturn environments, thus inducing managers to move from productive to financial investments. According to Lin and Tomaskovic-Devey (2013), this behaviour reflects the NFCs strategy of "growth fast in a slow-growth economy".

Fourthly, Akkemik and Özen (2014) advocate that macroeconomic uncertainty and increased risks together with institutional changes in corporate governance are the main reasons behind the rise in financial investments by NFCs. They tested these hypotheses using a panel data econometric analysis for 41 corporations quoted in Istanbul Stock Exchange for the period between 1990 and 2002. However, they found that this channel is mainly determined by highly uncertain macroeconomic environments and by the characteristics of corporations (such as size), whilst institutional features (e.g. close ties with the government, family ownership, discretion of managerial power and unionisation) do not have a statistical significant impact on financialisation. In fact, Baud and Durand (2012) stress that there is a greater preference for liquid assets in business environments characterised by high levels of uncertainty as the financial investments of NFCs represent a kind of "wait-and-see" strategy. In turn, NFCs involve themselves in financial activities through financial instruments, which hedge several risks against uncertainty (Soener, 2015).

Fifthly and following a neo-institutionalism perspective, Soener (2015) adds two further explanations to describe the growing importance of NFCs' financial investments. First, he stresses that NFCs learn to financialise with other corporations, i.e. the so-called "mimetic behaviour". Second, he emphasises that some actors (like financial executives or independent consultants) influence investors and managers to make more financial investments. Here, there is an institutional transmission of knowledge and practices from the know-how of these actors in the corporate finance field to the respective investors and managers.

Nonetheless, some authors (e.g. Fazzari et al., 1988; Gertler and Gilchrist, 1994; and Ndikumana, 1999) emphasise that the increase in financial receipts due to investments in financial activities and financial assets could exert a positive influence on productive investments if (and when) NFCs channel these financial incomes to make real investments. Orhangazi (2008a and 2008b) recognise that this could be a more relevant mechanism in the 
case of small and medium corporations since they face higher financial constrains and are therefore forced to use all incomes (even financial) to undertake real investments. However, the financialisation literature does not support this mechanism but argues that these financial incomes are normally re-invested in other financial activities and financial assets.

The second channel is associated with the strong pressures on NFCs to increase their financial payments (interest, dividends and/or stocks buybacks) to the financial markets and the respective shareholders. This limits the funds available for real investments, which is commonly referred to as the "profit without investment" hypothesis (Cordonnier and Van de Velde, 2014). As noted by Aglietta and Breton (2001) and Duménil and Lévy (2004), the higher levels of payout ratios reduce the funds available for real investments made by NFCs, which has had a negative effect on the execution of long-term investment projects including activities like innovation, research and development. Hein (2012) and Hein and Dodig (2015) term this the "internal means of finance channel". Once again, the literature on financialisation presents several explanations for the low retention ratios of NFCs.

Firstly, Orhangazi (2008a and 2008b) focuses on the high levels of NFCs indebtedness, which lead to a rise in financial payments in the form of interest.

Secondly and regarding the financial payments through dividends, he notes that managers are encouraged to raise short-term payout ratios and in fact it is in their interest to do so as their remuneration is based on the short-term evolution of stock prices. Their strategy is therefore to distribute high dividends because this tends to drive a short-term increase in stock prices. On the other hand, this is simply a response to pressures from shareholders who, in some cases, are institutional investors that seek constant appreciations in stock value and high payout ratios. If NFCs do not make these financial payments in the form of dividends, their stocks could decline sharply as demand for them would fall and supply increase, which could ultimately lead to a takeover.

Thirdly, Lazonick and O'Sullivan (2000) and Stockhammer (2010) argue that this growing trend of financial payments by NFCs over the last three decades is associated with a new design of corporate governance that favours the maximisation of shareholder value: the socalled "shareholder value orientation". Aglietta (2000) and van der Zwan (2014) notes that this has become "the norm of the transformation of capitalism" and is responsible for the dissemination of policies and practices that tend to favour shareholders over the other constituents of corporations. Lazonick and O'Sullivan (2000) suggest there has been a shift from "retain and reinvest" to a "downsize and distribute" strategy, namely a transfer from a strategy oriented to profit retention and reinvestment in corporations' growth to one of 
downsizing of corporate labour forces and the distribution of profits to shareholders. Levy-Orlik (2012) emphasises that investors' decisions based exclusively on the aim to maximise shareholder value target the reduction of production costs and rise in stock prices, to the detriment of employment, income equality, innovation and industrialisation.

Conversely and as referred by Orhangazi (2008a and 2008b), some authors claim that the increase in financial payments could be positive for NFCs' real investment on the grounds that higher levels of financial payments depend on higher profits and solvency. As such, these corporations will probably have access to more funding at lower costs, which could increase the implementation of new productive investments. However, this is not supported in the financialisation literature, which states that pressures to raise short-term financial payments are so strong and constant that NFCs cannot implement new real investments.

Despite the growing body of theoretical work on the effects of financialisation on real investment, there are few empirical studies on the subject, as emphasised by Onaran et al. (2011). Nevertheless, some empirical studies estimate investment functions for several countries in order to make an econometric analysis of financialisation's impact on real investment; most of these find it to be harmful ${ }^{2}$.

Stockhammer (2004) estimates an investment equation for Germany, France, UK and USA, using a time series econometric analysis for each country individually. He uses interest and dividends received (the so-called rentier income) by NFCs to measure financialisation, and concludes that it has led to a deceleration in real investment, particularly in the USA, France and UK. Orhangazi (2008a and 2008b) also identifies the deleterious effect of financialisation in the USA. He conducts a time series econometric analysis using aggregate data for NFCs as a whole and a panel data econometric analysis using micro data, analysing by sector (manufacturing versus non-manufacturing corporations), industry (durable versus non-durable producers) and dimension (small versus large corporations). In both studies, he applies financial profits (interest and dividends) and financial payments (interest, dividends and stock buybacks) to measure the two channels of financialisation. Van Treeck (2008) also performs a time series econometric analysis for the USA for the period between 1965 and 2004. He concludes that interest and dividend payments exert a negative influence on long-term non-financial investment in the USA. Onaran et al. (2011) estimate a simpler investment function, using a time series econometric analysis for the USA from 1962 to 2007. They found evidence supporting the

\footnotetext{
2 As demonstrated by Onaran et al. (2011) there are also some theoretical and empirical studies on the effects of financialisation in the other components of the aggregate demand. Here, we focus only on investment.
} 
claims that financialisation (proxied by interest and dividends payments) has suppressed the level of investment. Barradas and Lagoa (2014) also perform a time series econometric analysis focused on Portugal from 1977 and 2013, using a Vector Error Correction Model and financial receipts and financial profits of NFCs as proxies to capture financialisation. They conclude that financialisation has hurt real investment, mainly through financial payments and particularly in the long-term.

The literature has focused mainly on large and highly developed counties through time series econometric analyses for those countries. Here, we aim to make an empirical assessment of the relationship between financialisation and real investment of NFCs using a large set of countries, EU countries. To the best of our knowledge, this is the first paper conducting a panel data econometric analysis for a group of countries over time. This approach will allow us to perceive if the prejudicial effects of financialisation have been generalised and transversal to this large set of countries or only affected specific countries from a macroeconomic view point ${ }^{3}$.

\section{FINANCIALISATION AND REAL INVESTMENT: AN ECONOMIC MODELISATION}

Empirical studies of real investment are particularly difficult when they are carried out through econometric estimations of investment functions (Eisner, 1974). Effectively, "[...] estimation of investment functions is a tricky and difficult business and the best posture for any of us in that game is one of humility" (Eisner, 1974, p. 101). In the same vein, Davidson (2000) emphasises that investment equations do not follow a stable functional expression over time, since investment decisions are constantly affected by exogenous "animal spirits" of investors.

Nevertheless, there are several empirical studies of real investment in the literature that reveal various determinants of investment decisions. Stockhammer (2004) stresses the capacity utilisation, profitability and cost of capital as the main determinants of investment, while Orhangazi (2008a and 2008b) highlights real and financial variables, namely the level of profitability, output (or sales), cost of capital (or interest rates), degree of indebtedness and cash-flow (or the internal funds). Similarly, van Treeck (2008) states that the level of profitability and the business cycle are the main influencers of investment and Onaran et al.

\footnotetext{
3 From an econometric view point, the panel data econometric analysis has several other advantages over a simple time series econometric analysis, as pointed out by Baltagi (2005), Brooks (2008), among others. 
(2001) refers to output (that captures the accelerator effect) and the level of profitability (that indicates the availability of funds) as particularly influential.

In what follows, we estimate an equation where investment is a function of the prevalent variables in the explanation of investment decisions of investors in NFCs: profitability, level of debt, cost of capital, savings rate and output growth. Additionally, we incorporate two further variables (financial receipts and financial payments) to account for the two channels related with financialisation's prejudicial effects on productive investments, as described previously.

Accordingly, our investment function takes the following form:

$$
\begin{aligned}
I_{i, t}= & \beta_{0}+\beta_{1} P_{i, t-1}+\beta_{2} D_{i, t-1}+\beta_{3} C C_{i, t-1}+\beta_{4} S R_{i, t-1}+ \\
& +\beta_{5} O G_{i, t-1}+\beta_{6} F R_{i, t-1}+\beta_{7} F P_{i, t-1}+\mu_{i, t}
\end{aligned}
$$

, where $i$ is the country, $t$ is the time period (years), $I$ is investment of NFCs, $P$ is profitability of NFCs, $D$ is the corporate debt of NFCs, $C C$ is the cost of capital, $S R$ is the savings rate, $O G$ is the output growth, $F R$ are financial receipts of NFCs and $F P$ are financial payments of NFCs.

The two-way error term component is given by:

$$
\mu_{i, t}=\eta_{i}+\lambda_{t}+\varepsilon_{i, t}
$$

, where $\eta_{i}$ accounts for unobservable country-specific effects and $\lambda_{t}$ accounts for timespecific effects. The term $\varepsilon_{i, t}$ is the random disturbance in the regression, varying across countries and years.

We use lagged values for the independent variables because of the time lag between investment decisions and the respective capital expenditures (investment projects usually take over one year to be implemented, meaning that the decision to invest in $t$ was based with information in $t-1$ ), the role on the formation of investors' expectations (adaptive expectations) and the need to avoid potential problems of simultaneity and reverse causation (i.e. endogeneity problems) (Orhangazi, 2008a and 2008b). On one hand, profits (where financial receipts and financial payments are included) of a certain year are only available for investments in the following year. On the other, investors only know the lagged values of output growth when they make investment decisions.

DINÂMIA'CET - IUL, Centro de Estudos sobre a Mudança Socioeconómica e o Território ISCTE-IUL - Av. das Forças Armadas, 1649-026 Lisboa, PORTUGAL 
All NFCs variables (investment, profitability, debt, financial receipts and financial payments) are expressed as ratios of the respective gross value added (both the numerator and denominator are in volume). This permits the comparison of variables expressed in different currencies, making exchange rates unnecessary for conversion to the same currency that could skew results due to the respective movements on international financial markets. This also allows the respective coefficients to be interpreted in percentage points (p.p.).

It should be noted that we propose to estimate an aggregate investment function, similarly to Stockhammer (2004), Orhangazi (2008a), van Treeck (2008), Onaran et al. (2011) and Barradas and Lagoa (2014). Stockhammer (2004) emphasises that the respective results should be analysed with care as we are addressing a macroeconomic issue, i.e. the slowdown of real investment, although the theory of NFCs investment decisions is supported by microeconomic fundaments. This strategy implies the assumption of a representative corporation. In addition, we recognise some limitations to this approach since the use of an aggregate investment function does not reflect different financialisation levels among NFCs or the potential dissimilarities in the behaviour of NFCs from different countries, sectors, industries, dimensions and/or ownerships. Note also that as a panel data econometric analysis estimates an average effect of several countries, it does not account for the historical, social and economic circumstances responsible for real investment in each country. Here, we follow a macroeconomic perspective to assess whether financialisation has been beneficial or prejudicial to real investment in the EU. Thus, if the two channels of financialisation are found to have a macroeconomic effect, we cannot determine whether it is due to the impact of some corporations/countries or is more generalised across all corporations/countries. If we do not find any macroeconomic effect, we cannot exclude that they affect a subset of corporations/countries, which however is not enough to create a macroeconomic effect in all countries.

Accordingly, profitability, savings rate and output growth are expected to exert a positive influence on investment, while cost of capital and the two variables of financialisation are expected to influence NFCs investment negatively. The level of debt could have a positive or a negative influence on investment. Thus, coefficients of these variables are expected to have the following signs:

$$
\beta_{1}>0, \beta_{2} \gtrless 0, \beta_{3}<0, \beta_{4}>0, \beta_{5}>0, \beta_{6}<0, \beta_{7}<0
$$


Profitability is expected to exert a positive influence on real investment, mirroring the demand conditions that are crucial to determine the viability of investment projects. Effectively and following a Keynesian argument, profitability tends to have a positive effect on real investment by functioning as a source of internal funds (Stockhammer, 2004). Kopche and Braunman (2001) note that expectations for future demand conditions and future profitability have the strongest influence on investment. Nonetheless, Kuh and Meyer (1955) and Minsky (1975) state that given the uncertainty about the future it is the past demand conditions and past profitability rather than the expectations that are the major influencers of investment. This seems to prevent the anticipation of future demand conditions and future levels of profitably, in a context where these expectations are normally formed on the basis of past.

The debt level has an undetermined effect on investment (Orhangazi, 2008a and 2008b). A positive effect is expected when the debt level is perceived to be safe. Here, a rise in debt may have no effect or even a positive effect on investment by increasing the available funds. A negative effect occurs when the debt level is perceived to be unsafe, as it signals greater financial fragility and makes it more difficult to obtain further funding. In that situation, future profits may be insufficient to repay existing debt, increasing the probability of bankruptcy.

The cost of capital (normally measured by the level of real long-term interest rates) is expected to exert a negative effect on real investment, reflecting the funding costs or the respective opportunity costs.

In addition, real investment is expected to depend positively on the respective savings rate, because a higher savings rate tends to be associated with a higher level of funds in the hands of banks and/or international financial markets, which is determinant to their intermediation function and the provision of funding to corporations (by transferring savings from lenders to borrowers in credit or other forms of financing).

On the other hand, real investment also depends positively on the output growth. This follows the Keynesian argument of the accelerator principle that most investors exhibit a higher propensity to invest in periods of economic growth than during downturns. The accelerator principle postulates that an acceleration/deceleration of the GDP will accelerate/decelerate real investment even more, given a multiplier higher than one. Lopes (2003) confirms that real investment in the EU and the USA is strongly procyclical in relation to the respective business cycle. Indeed, Sørensen and Whitta-Jacobsen (2005) highlight the existence of two stylised facts of business cycles in relation to investment: investment is strongly positively correlated with the business cycle; and it is the most volatile component of aggregate demand.

DINÂMIA'CET - IUL, Centro de Estudos sobre a Mudança Socioeconómica e o Território ISCTE-IUL - Av. das Forças Armadas, 1649-026 Lisboa, PORTUGAL 
Financialisation and real investment in the European Union using a country-level analysis: beneficial or prejudicial effects?

Finally and as discussed in the previous Section, the two financialisation variables are expected to exert a negative influence on NFCs' real investment. On one hand, the rise in financial receipts tends to lower real investment as NFCs will use this income to make further investments in financial activities and/or in financial assets rather than to investment in real activities ("crowding out" effect). On the other, financial payments also tend to lower real investment because they reduce the funds available for these real investments.

\section{DATA AND METHODOLOGY: THE ECONOMETRIC FRAMEWORK}

\subsection{Data}

In order to analyse the role of financialisation on real investment of EU countries, we collect annual data from 1995 and 2013 for a set of 27 countries (Austria, Belgium, Bulgaria, Cyprus, Czech Republic, Denmark, Estonia, Finland, France, Germany, Greece, Hungary, Ireland, Italy, Latvia, Lithuania, Luxembourg, Netherlands, Norway, Poland, Portugal, Romania, Slovakia, Slovenia, Spain, Sweden and United Kingdom). Malta was the only EU country excluded, due to the lack of data. Table 1 shows the sample period and the number of observations and missing per country.

Table 1 - Sample composition

\begin{tabular}{c|c|c|c}
\hline Country & Period & Observations & Missing \\
\hline Austria & $1995-2013$ & 19 & 0 \\
Belgium & $1995-2013$ & 19 & 8 \\
Bulgaria & $2002-2012$ & 11 & 3 \\
Cyprus & $1997-2012$ & 16 & 0 \\
Czech Republic & $1995-2013$ & 19 & 0 \\
Denmark & $1995-2013$ & 19 & 2 \\
Estonia & $1996-2012$ & 17 & 1 \\
Finland & $1995-2012$ & 18 & 0 \\
France & $1995-2013$ & 19 & 0 \\
Germany & $1995-2013$ & 19 & 11 \\
Greece & $2005-2012$ & 8 & 0 \\
Hungary & $1995-2013$ & 19 & 7 \\
Ireland & $2002-2013$ & 12 & 0 \\
Italy & $1995-2013$ & 19 & 2 \\
Latvia & $1997-2013$ & 17 & 5 \\
Lithuania & $1999-2012$ & 14 & 12 \\
Luxembourg & $2006-2012$ & 7 & 0 \\
Netherlands & $1995-2013$ & 19 & 1 \\
Norway & $1995-2012$ & 18 & 1 \\
Poland & $1995-2012$ & 18 & 0 \\
Portugal & $1995-2013$ & 19 & 2 \\
Romania & $1995-2011$ & 17 & 0 \\
Slovakia & $1995-2013$ & 19 & 3 \\
Slovenia & $1998-2013$ & 16 & 5 \\
Spain & $2000-2013$ & 14 & 0 \\
Sweden & $1995-2013$ & 19 & 0 \\
United Kingdom & $1995-2013$ & 19 & \\
\hline
\end{tabular}

DINÂMIA'CET - IUL, Centro de Estudos sobre a Mudança Socioeconómica e o Território ISCTE-IUL - Av. das Forças Armadas, 1649-026 Lisboa, PORTUGAL

Tel. 210464031 - Extensão 293100 E-mail: dinamia@iscte.pt http://dinamiacet.iscte-iul.pt/ 
This is the period and the frequency for which all data are available and they are suitable for the study for two reasons. First, financialisation became more preponderant in the 1990s (van der Zwan, 2014); second, the investment by corporations is a long-term decision (it usually takes over a year to implement investment projects and recover the invested capital), and therefore annual data is likely to capture the determinants of real investment better than higher frequency data.

Thus, we construct a panel of data (or longitudinal data), since we collect data for a set of 27 cross-sectional units $(N=27)$ that were observed over time between 1995 and 2013 $(T=19)$. Nonetheless, we obtained an unbalanced panel data because it was impossible to collect data for all years for each country. We have 63 missing values and our sample is therefore composed of a total of 450 observations.

Table A1 in Appendix contains the descriptive statistics of the data and Table 2 presents the corresponding correlation matrix between all variables. The most important finding is that the absolute values of all correlations are lower than 0.8 , which is crucial to exclude the existence of severe multicollinearity between the variables of our model (Studenmund, 2005). In addition, profitability and output growth are the only variables positively correlated with investment; indeed they are precisely the two variables expected to have a positive effect on investment. The variables of debt, cost of capital, financial receipts and financial payments are negatively correlated with investment, which could signal a negative effect on investment. This also seems to confirm our suspicion that financialisation has hampered real investment through the two aforementioned channels.

Table 2 - The correlation matrix between variables

\begin{tabular}{l|cccccccc}
\hline & $\boldsymbol{I}$ & $\boldsymbol{P}$ & $\boldsymbol{D}$ & $\boldsymbol{C C}$ & $\boldsymbol{S R}$ & $\boldsymbol{O G}$ & $\boldsymbol{F R}$ & $\boldsymbol{F P}$ \\
\hline $\boldsymbol{I}$ & 1 & & & & & & & \\
$\boldsymbol{P}$ & $0.139^{* * *}$ & 1 & & & & & & \\
$\boldsymbol{D}$ & $-0.531^{* * *}$ & $0.139^{* * *}$ & 1 & & & & & \\
$\boldsymbol{C} \boldsymbol{C}$ & $-0.122^{* * *}$ & -0.037 & $0.278^{* * *}$ & 1 & & & & \\
$\boldsymbol{S R}$ & $-0.378^{* * *}$ & $-0.493^{* * *}$ & -0.014 & $0.117^{* *}$ & 1 & & & \\
$\boldsymbol{O G}$ & $0.313^{* * *}$ & $0.151^{* * *}$ & $-0.327^{* * *}$ & $-0.311^{* * *}$ & $-0.234^{* * *}$ & 1 & & \\
$\boldsymbol{F R}$ & $-0.288^{* * *}$ & $-0.323^{* * *}$ & -0.016 & -0.077 & $0.316^{* * *}$ & $-0.174^{* * *}$ & 1 & \\
$\boldsymbol{F P}$ & $-0.364^{* * *}$ & 0.044 & $-0.102^{* *}$ & -0.014 & $0.316^{* * *}$ & $-0.177^{* * *}$ & $0.730^{* * *}$ & 1 \\
\hline
\end{tabular}

Note: $* * *$ indicates statistical significance at $1 \%$ level and $* *$ indicates statistical significance at $5 \%$ level

Regarding the definition of the data, we used the gross fixed capital formation of NFCs divided by the respective gross value added to describe the NFCs' investment. The ratio between these two variables is usually known as the NFCs' investment rate.

DINÂMIA'CET - IUL, Centro de Estudos sobre a Mudança Socioeconómica e o Território ISCTE-IUL - Av. das Forças Armadas, 1649-026 Lisboa, PORTUGAL 
We use the NFCs' gross operating surplus ${ }^{4}$ divided by the respective gross value added as a proxy of profitability; the ratio between these two variables is commonly referred to as the profit share of NFCs.

The proxy of the debt level used here was the net lending/net borrowing ${ }^{5}$ of NFCs divided by the respective gross value added.

Financial receipts correspond to the sum of interest and the distributed income of corporations $^{6}$ (where dividends are included) received by NFCs. We divided them by the gross value added of NFCs.

We use the sum of interest and the distributed income of corporations (where dividends are included) paid by NFCs as a proxy of financial payments. We also divided them by the gross value added of NFCs.

Note that the variables of gross fixed capital formation, gross value added, gross operating surplus, net lending/net borrowing, financial receipts and financial payments of NFCs were collected from the European Sector Accounts (at current prices and in millions of national currency), available at Eurostat. When not available on Eurostat, observations of these variables were completed with data from the national statistic offices of each country.

We use the long-term real interest rates (deflated by the GDP deflator) from AMECO database to measure the cost of capital of NFCs. For some countries, we also used the shortterm real interest rates (deflated by the GDP deflator) for several years because in the case of some countries (Czech Republic, Estonia, Hungary, Latvia, Lithuania, Norway, Poland, Romania, Slovakia and Slovenia) long-term real interest rates are only available for the most recent years ${ }^{7}$. We chose this strategy instead of using only the short-term real interest rates for all countries because investment is a long-term decision and is therefore more dependent on long-term interest rates.

\footnotetext{
${ }^{4}$ According to the Eurostat, "gross operating surplus can be defined in the context of national accounts as a balancing item in the generation of income account representing the excess amount of money generated by incorporated enterprises' operating activities after paying labour input costs. In other words, it is the capital available to financial and non-financial corporations which allows them to repay their creditors, to pay taxes and eventually to finance all or part of their investment".

${ }^{5}$ The net lending/net borrowing of non-financial corporations is the difference between current savings (plus capital transfers) and the respective investment. According to the OECD, "it reflects the amount of financial assets that are available for lending or needed for borrowing to finance all expenditures current, gross capital formation, non-produced non-financial assets, and capital transfers - in excess of disposable income". As such, a country is net lender/net borrower when it exhibits positive/negative values of net lending/net borrowing.

6 The distributed income of corporations includes dividends and withdrawals from the income of quasicorporations (amounts that entrepreneurs withdraw for their own use from the profits earned by the quasi-corporations that belong to them).

7 According to the AMECO database, the real interest rates are obtained by the difference between the nominal interest rates and the inflation rate measured by the GDP deflator.
} 
The savings rate variable corresponds to the gross savings of households as a percentage of the respective disposable income, available on AMECO database.

Finally, we apply the usual variable of gross domestic product to describe the evolution of output growth. It was collected from the Eurostat (at current prices and in millions of national currency) and was deflated using the GDP deflator (2005=100), available on AMECO database. After that, we calculate the respective annual growth rate.

\subsection{Methodology}

Our methodology involves four steps. Note that we assume the stationarity of our data for the following three reasons. First, plots of our eight variables (Figure A1 to Figure A8 in Appendix) already seem to indicate that all variables are stationary in levels. Second, our variables are in fact defined in ratios (in the case of investment, profitability, debt, savings rate, financial receipts and financial payments) or in growth rates (in the case of output growth); intuitively it is plausible to assume that these variables do not exhibit a unit root. Third, the traditional panel unit root tests have low power and perform very poorly in the presence of panels where the cross-sectional dimension $N$ is higher than the period dimension $T$, as recognised by Baltagi (2005), Hlouskova and Wagner (2006), Cameron and Trivedi (2009), among others. These authors also emphasise that for small $T$, there is the potential risk of concluding that the whole panel in non-stationary even when the panel has a large proportion of stationary data, since the conventional panel unit root tests tend to assume that $T \rightarrow \infty$.

Therefore, we must first decide which is the best econometric panel technique to make our estimations. There are several analytical models, namely the Pooled Ordinary Least Squares (POLS), the Fixed-Effects (FE) and the Ramdom-Effects (RE). We will perform the Breusch and Pagan Lagrangian Multiplier test and the Hausman (1978) specification test $^{8}$ to decide whether there are individual effects and if these effects are fixed or random.

Having done this, we will make some diagnostic tests to determine whether our panel suffers from problems such as heteroscedasticity, autocorrelation of the residuals and/or crosssectional dependence, because these disturbances are usually present in most macroeconomic empirical applications and they tend to affect the performance of panel estimators, as recognised by Hoechle (2007), Reed and Ye (2011), among others. We will apply a period heteroscedasticity test and a cross-sectional heteroscedasticity test ${ }^{9}$, based on Levene (1960) and

\footnotetext{
$\mathbf{8}$ We apply, respectively, the "xttest0" and the "hausman" commands from Stata software.

9 We follow the "robvar" instruction from Stata software.
} 
Brown and Forsythe (1974). This test reports Levene's robust test statistic $\left(\mathrm{W}_{0}\right)$ for the equality of variances and the two statistics proposed by Brown and Forsythe (1974) that replace the mean in Levene's formula with the median $\left(\mathrm{W}_{50}\right)$ and with the $10 \%$ trimmed mean $\left(\mathrm{W}_{10}\right)$ because these two reformulations have been proved more robust in the presence of skewed populations. We also apply a modified Wald statistic to test a group-wise heteroscedasticity ${ }^{\mathbf{1 0}}$, following Greene (2000). In addition, we perform the Wooldridge (2002) test for serial correlation ${ }^{11}$. Drukker (2003) emphasises that this test has good size and power properties even in reasonably sized samples. Finally, we conduct a cross-sectional dependence test ${ }^{12}$, based on three different testing procedures: Friedman's (1937) test statistic, the statistic proposed by Frees (1995 and 2004) and the cross-sectional dependence test of Pesaran (2004). As noted by Hoyos and Sarafidis (2006), all these three procedures may be suitable if the panel's crosssectional dimension $N$ is higher than the period dimension $T$ and the model is static.

The third step is the estimation of our model. As we will see in the next Section, our panel suffers from heteroscedasticity, autocorrelation of the residuals and cross-sectional dependence. Hoechle (2007) notes that three different estimators can be used to deal with this. Firstly, he presents the Feasible Generalised Least Squares (FGLS) proposed by Parks (1967), but stresses that it is not feasible if the panel's period dimension $T$ is smaller than its crosssectional dimension $N$ and tends to produce unacceptably small standard error estimates. Secondly, he introduces the methodology proposed by Beck and Katz (1995), using Ordinary Least Squares (OLS) coefficient estimates with Panel Corrected Standard Errors (PCSE). Nevertheless, he recognises that the finite sample properties of the PCSE estimator are quite poor when the panel's cross-sectional dimension $N$ is higher than the period dimension $T$. Thirdly, he presents the Driscoll and Kraay (1998) estimator, emphasising that it applies a Newey-West type correction to the sequence of cross-sectional averages of the moment conditions. He states this estimator is suitable for both balanced and unbalanced panels and consistent when the panel's cross-sectional dimension $N$ is higher than the period dimension $T$, which is our case. Therefore, we will use this estimator for our investment function ${ }^{13}$.

\footnotetext{
${ }^{10}$ We use the "xttest3" command from Stata software.

11 We apply the "xtserial" instruction from Stata software.

${ }^{12}$ As we have a panel where the cross-sectional dimension $N$ is higher than the period dimension $T$, we cannot perform the traditional Lagrange Multiplier test, developed by Breusch and Pagan (1980) and following Greene (2000), through the command "xttest2" in Stata software. We therefore use the "xtcsd" command from Stata software.

${ }^{13}$ We follow the "xtscc" instruction from Stata software. Note that this estimator performs a POLS with Driscoll and Kraay standard errors.
} 
Finally, we analyse the estimations of our investment equation for EU countries and make a simple robustness analysis in order to assess whether the results exhibit some sensitivity to other specifications, namely distinguishing between receipts and payments of interest and dividends, and differentiating between the more and the less financialised countries.

\section{EMPIRICAL RESULTS AND DISCUSSION}

First, we need to address the correct model specification to determine whether there are individual effects in our panel, i.e. country-specific effects that differentiate each country, are not observed and do not change over time. These individual effects can be either fixed or random. We apply the Breusch and Pagan Lagrangian Multiplier test and the Hausman test and the respective results are presented in Table 3. In relation to the LM test, we strongly reject the null hypothesis that variances across countries are zero. So we have evidence that there are significant differences across countries, i.e. there are individual effects. Regarding the Hausman test, we cannot reject the null hypothesis that the RE model is preferable to the FE model. We therefore conclude that the RE model is the best econometric specification for our panel.

Table 3 - The Breusch and Pagan Lagrangian Multiplier (LM) test and the Hausman test

\begin{tabular}{c|c|c}
\hline Test & Chi-square & P-value \\
\hline LM test & 990.76 & 0.000 \\
Hausman test & 4.89 & 0.674 \\
\hline
\end{tabular}

We then conduct a set of diagnostic tests to assess whether our RE model suffers from any disturbance. We apply five different tests and the respective results are presented in Table 4. In relation to the period and the cross-sectional heteroscedasticity tests, we reject the null hypothesis that the variances are equal (homocedasticity), concluding that our panel suffers from heterocedasticity. Note that we cannot perform the group-wise heteroscedasticity test because it is not available for the RE models. For the serial correlation test, the null hypothesis of no serial correlation is clearly rejected and it is concluded that our panel suffers from autocorrelation of the residuals. Finally and regarding the cross-sectional dependence, the null hypothesis of cross-sectional independence cannot be rejected by the Friedman test. However, the null hypothesis of cross-sectional independence is rejected by Frees test and Pesaran test. Therefore, we will assume the existence of cross-sectional dependence in our panel as this is the result of two of the three tests performed.

DINÂMIA'CET - IUL, Centro de Estudos sobre a Mudança Socioeconómica e o Território ISCTE-IUL - Av. das Forças Armadas, 1649-026 Lisboa, PORTUGAL 
Financialisation and real investment in the European Union using a country-level analysis: beneficial or prejudicial effects?

Table 4 - Diagnostic tests for the RE model

\begin{tabular}{|c|c|c|c|}
\hline \multicolumn{2}{|c|}{ Test } & Statistic & P-value \\
\hline \multirow{3}{*}{$\begin{array}{c}\text { Period } \\
\text { Heteroscedasticity }\end{array}$} & $\mathbf{W}_{0}$ & 3.071 & 0.000 \\
\hline & $W_{50}$ & 2.343 & 0.002 \\
\hline & $W_{10}$ & 2.873 & 0.000 \\
\hline \multirow{3}{*}{$\begin{array}{c}\text { Cross-sectional } \\
\text { Heteroscedasticity }\end{array}$} & $\mathbf{W}_{0}$ & 8.050 & 0.000 \\
\hline & $W_{50}$ & 5.577 & 0.000 \\
\hline & $\mathrm{W}_{10}$ & 7.311 & 0.000 \\
\hline \multicolumn{2}{|c|}{$\begin{array}{c}\text { Group-wise Heteroscedasticity } \\
\text { Serial Correlation }\end{array}$} & $\begin{array}{l}\text { n. a. } \\
46,374\end{array}$ & $\begin{array}{l}\text { n. a. } \\
0,000\end{array}$ \\
\hline $\begin{array}{l}\text { Cross-sectional } \\
\text { Dependence }\end{array}$ & $\begin{array}{l}\text { Friedman } \\
\text { Frees } \\
\text { Pesaran }\end{array}$ & $\begin{array}{l}25.741 \\
1.566 \\
6.778\end{array}$ & $\begin{array}{l}0.477 \\
\text { n. a. } \\
0.000\end{array}$ \\
\hline
\end{tabular}

Note: The critical values from Frees' $Q$ distribution (T-asymptotically distributed) are 0.489, 0.686 and 1.105 to the significance levels of $10 \%, 5 \%$ and $1 \%$, respectively

We then proceed with the estimation of our investment function. As our panel suffers from heteroscedasticity, serial correlation of the respective residuals and cross-sectional dependence, we use the Driscoll and Kraay (1998) estimator and the respective results are in Table 5.

All variables are statistically significant at the conventional significance levels, with the exception of cost of capital and output growth. Even so, the variable of output growth has the expected positive sign, partially confirming that investors are more willing to invest in periods of economic growth and that investment is procyclical in relation to the business cycle. However, the respective coefficient is less than one, which does not confirm the accelerator principle. On the other hand, all coefficients of the statistically significant variables have the expected signals, with the exception of savings rate and financial receipts. Indeed, NFCs' investment is positively influenced by the level of profitability, which may suggest that profits are used to finance real investments. Alternatively, a higher profitability rate may indicate that future projects will be more profitable and thus induces more investment. A 1 p.p. increase in profitability raises investment by about 0.3 p.p.. The debt level exerts a negative influence on the NFCs' investment: a 1 p.p. increase in the level of debt reduces real investment by around 0.45 p.p.. This indicates that the debt level of NFCs has reached an unsafe level, making it more difficult to obtain further funding. This also suggests that debt is being used to repay existing debts rather than to fund new investments. The real investment of NFCs also depends negatively on the savings rate: a 1 p.p. increase in the savings rate lowers investment by about 0.2 p.p.. This (unexpected) negative coefficient of the savings rate could have two different explanations. First, it could indicate that banks in EU countries are not so dependent on household savings to guarantee their intermediation function, namely because they have access to other forms of financing (e.g. foreign financing). Second, it could be associated simply with the negative relationship between savings and consumption. In fact, a higher level of savings involves lower consumption by households, which can slow down the new investments made by corporations. Financial receipts exert a positive influence on real investment, contrary to the claims 
of the literature on financialisation. A 1 p.p. rise in financial receipts raises investment by about 0.3 p.p.. This seems to exclude the "crowding out" assumption. This positive relationship reveals that financial investments have not been detrimental to real investments, probably because NFCs use financial returns to finance real investments. Finally, real investment is negatively influenced by financial payments in line with the literature on financialisation. A 1 p.p. increase in financial payments reduces investment by about 0.5 p.p.

Table 5 - Estimations of the investment function

\begin{tabular}{c|c|c|c}
\hline Variable & Coefficient & Standard Error & T-statistic \\
\hline $\boldsymbol{P}_{t-1}$ & $0.279^{* * *}$ & 0.060 & 4.69 \\
$\boldsymbol{D}_{t-1}$ & $-0.447^{* * *}$ & 0.071 & -6.27 \\
$\boldsymbol{C} \boldsymbol{C}_{t-1}$ & 0.109 & 0.091 & 1.20 \\
$\boldsymbol{S} \boldsymbol{R}_{t-1}$ & $-0.150^{*}$ & 0.077 & -1.95 \\
$\boldsymbol{O \boldsymbol { G } _ { t - 1 }}$ & 0.099 & 0.076 & 1.31 \\
$\boldsymbol{F R}_{t-1}$ & $0.252^{* * *}$ & 0.049 & 5.11 \\
$\boldsymbol{F P}_{t-1}$ & $-0.475^{* * *}$ & 0.056 & -8.47 \\
$\boldsymbol{\beta}_{\boldsymbol{\theta}}$ & $0.206^{* * *}$ & 0.024 & 8.75 \\
\hline
\end{tabular}

Note: $* * *$ indicates statistical significance at $1 \%$ level and $*$ indicates statistical significance at $10 \%$ level

To obtain a better understanding of the effects of financialisation on NFCs' real investment in EU countries, we also re-estimate the investment function equation, splitting financial receipts into interest and dividends receipts ( $I R$ and $D R$, respectively) and dividing financial payments into interest and dividends payments ( $I P$ and $D P$, respectively). Once again, the RE model proved to be the best econometric specification to estimate the investment function, according to the Breusch and Pagan Lagrangian Multiplier test and the Hausman test (Table A2 in Appendix). We maintain the Driscoll and Kraay (1998) estimator because our investment function defined in this particular way continues to suffer from heteroscedasticity, serial correlation of the respective residuals and cross-sectional dependence (Table A3 in Appendix). The respective results are presented in Table 6.

Table 6 - Estimations of the investment function with financial receipts and financial payments divided between interest and dividends

\begin{tabular}{|c|c|c|c|}
\hline Variable & Coefficient & Standard Error & T-statistic \\
\hline$P_{t-1}$ & $0.296 * * *$ & 0.056 & 5.29 \\
\hline$D_{t-1}$ & $-0.454 * * *$ & 0.072 & -6.30 \\
\hline$C C_{t-1}$ & 0.132 & 0.080 & 1.64 \\
\hline$S R_{t-1}$ & $-0.132 *$ & 0.070 & -1.88 \\
\hline$O G_{t-1}$ & $0.109^{*}$ & 0.059 & 1.84 \\
\hline$I R_{t-1}$ & -0.087 & 0.202 & -0.43 \\
\hline$D R_{t-1}$ & $0.395 * * *$ & 0.077 & 5.13 \\
\hline$I P_{t-1}$ & $-0.470 * * *$ & 0.117 & -4.02 \\
\hline$D P_{t-1}$ & $-0.507 * * *$ & 0.059 & -8.60 \\
\hline$\beta_{0}$ & $0.206 * * *$ & 0.022 & 9.35 \\
\hline
\end{tabular}


Overall, the results do not change dramatically. In fact, all variables remain statistically significant at the traditional significance levels, with the exception of cost of capital. At the same time, the level of profitability continues to influence investment positively and the debt level and savings rate also exerts a negative influence on NFCs' real investment. Here, the most important change is related with the output growth variable, which becomes statistically significant and continues to influence investment positively, reinforcing the procyclical nature of investment. Similarly, financial payments continue to exert a negative influence on real investment, not only through interest payments but also through dividends. This shows us that the debt service and the paradigm of "shareholder value orientation" have been simultaneously detrimental to NFCs' real investment in the EU. Nevertheless, the "shareholder value orientation" seems to be more harmful for real investment, given the lower coefficient of dividends payments in relation to the coefficient of interest payments. However, we conduct a simple Wald test to determine whether the two coefficients are statistically equal (Table A4 in Appendix). We cannot reject the null hypothesis and conclude that they are statistically equal. The channel of financial receipts exhibits mixed results. Indeed, interest receipts are a negative determinant to real investment but cease to have statistical significance. This seems to give a tenuous indication that the returns of financial investments in debt securities are being used to finance further financial activities or financial investments, confirming the hypothesis of the "crowding out" effect. Nevertheless, dividends receipts remain statistically significant and maintain a positive sign, strengthening the claims that NFCs in EU countries could be using their financial returns from shares to make new real investments.

Our next aim is to discover whether financialisation has affected both more financialised and less financialised countries in the same manner and/or degree. We re-estimate our aggregate investment function, adding two dummy variables for the more financialised countries in terms of financial receipts and financial payments ( $D F R$ and $D F P$, respectively). We calculated the average of financial receipts and financial payments for each country during the period for which both variables are available (Table A5 in Appendix). After, we split the different countries into those with more and fewer financial receipts and those with more and fewer financial payments, respectively, in relation to the overall average of all countries (Table A6 in Appendix). The more financialised countries in terms of financial receipts and financial payments take the value one in the dummy variables $D F R$ and $D F P$, respectively ${ }^{14}$. These

14 Note that DFR takes the value 1 for Belgium, Cyprus, Denmark, Finland, France, Hungary, Luxembourg, Netherlands, Norway and Sweden; and the value 0 for the remaining countries. DFP takes 
two dummies are then multiplied by the two respective financialisation variables in order to determine whether there is a relationship between investment and the extent of the countries' financialisation.

Here, the FE model seem to be the best econometric specification to estimate our investment function defined in this manner, according to the the Breusch and Pagan Lagrangian Multiplier test and the Hausman test (

Table A7 in Appendix). However, we maintain the Driscoll and Kraay (1998) estimator because our investment function defined in this particular specification continues to suffer from heteroscedasticity, serial correlation of the respective residuals and cross-sectional dependence (Table A8 in Appendix). The respective results are presented in Table 7.

Table 7 - Estimations of the investment function with two dummies for the countries that exhibit higher levels of financial receipts and higher levels of financial payments

\begin{tabular}{|c|c|c|c|}
\hline Variable & Coefficient & Standard Error & T-statistic \\
\hline$P_{t-1}$ & $0.298 * * *$ & 0.043 & 6.86 \\
\hline$D_{t-1}$ & $-0.436 * * *$ & 0.073 & -6.02 \\
\hline$C C_{t-1}$ & 0.109 & 0.094 & 1.15 \\
\hline$S R_{t-1}$ & $-0.144 *$ & 0.074 & -1.95 \\
\hline$O G_{t-1}$ & 0.128 & 0.092 & 1.40 \\
\hline$F R_{t-1}$ & $0.358 *$ & 0.183 & 1.95 \\
\hline$D F R^{*} F R_{t-1}$ & -0.090 & 0.148 & -0.61 \\
\hline $\boldsymbol{F P} \boldsymbol{P}_{t-1}$ & $-0.410 * * *$ & 0.053 & -7.70 \\
\hline$D F P * F P_{t-1}$ & $-0.052 * *$ & 0.019 & -2.79 \\
\hline$\beta_{0}$ & $0.185 * * *$ & 0.016 & 11.69 \\
\hline
\end{tabular}

Note: $* * *$ indicates statistical significance at $1 \%$ level, $* *$ indicates statistical significance at $5 \%$ level and $*$ indicates statistical significance at $1 \%$ level

On aggregate, the results are quite similar. Once again, all variables are statistically significant at the traditional significance levels with the exception of cost of capital and output growth. In the same fashion, the profitability level remains a positive determinant of NFCs' real investment, whilst the debt level and the savings rate maintain their negative influence on real investment. The variables linked with financialisation also suffer no significant changes. Financial receipts continue to influence real investment positively, strengthening our argument that financial investments made by NFCs are not diverting substantial funds from real investments. Instead, these financial incomes seem to be used as a source of funding for new investment. Financial payments maintain their negative coefficient, confirming that lower retention ratios are disruptive for NFCs' real investment. The most important findings are

the value 1 for Belgium, Cyprus, Finland, France, Germany, Greece, Ireland, Italy, Latvia, Lithuania, Luxembourg, Norway and Sweden; and the value 0 for the remaining countries. 
related with the dummies variables, which are negative in both cases (albeit statistically insignificant in the case of financial receipts). This seems to illustrate that real investment in more financialised countries is more adversely affected than in less financialised countries.

In conclusion, we find evidence supporting the claim that financialisation has hurt NFCs' real investment in EU countries, mainly due to the channel involving the strong pressures on NFCs to increase their payments to shareholders in the form of interest and dividends. We are also able to identify that the prejudicial effects of financialisation are worse in the more financialised countries. Another important conclusion is that there is a disruptive relationship between debt and real investment, which suggests that NFCs in EU countries use new debts to repay existing debts rather than to implement new productive investments. Our results are therefore in line with other empirical studies that find a negative relationship between financialisation and real investment (Stockhammer, 2004; Orhangazi, 2008a and 2008b; van Treeck, 2008; Onaran et al., 2011; and Barradas and Lagoa, 2014) and between debt and real investment (Orhangazi, 2008b ${ }^{15}$; Barradas and Lagoa, 2014).

\section{CONCLUSION}

This paper aimed to determine whether financialisation has beneficial or prejudicial effects on real investment in EU countries by conducting a panel data econometric analysis for $27 \mathrm{EU}$ countries from 1995 and 2013, using macroeconomic annual data.

As opposed to mainstream economics, the literature on financialisation refers to two channels through which the increasing importance of finance could be disruptive to the real investment of NFCs. Firstly, the rise of in financial investments made by NFCs deviates funds from productive investments, causing a type of "crowding out" effect on real investment. Secondly, the funds available to support real investments have decreased due to the strong pressure from shareholders on NFCs for financial payments in the form of interest, dividends and/or stock buybacks.

We estimate an investment equation to describe real investment using macroeconomic annual data and making use of the standard variables (profitability, debt, cost of capital, savings rate and output growth) and two other variables to reflect the two channels of financialisation (financial receipts and financial payments).

We conclude that the RE model is the best econometric specification and that our panel suffers from heteroscedasticity, autocorrelation of the residuals and cross-sectional dependence.

15 Orhangazi (2008a) finds that debt has a positive influence on real investment, but lacks statistical significance at the traditional significance levels.

DINÂMIA'CET - IUL, Centro de Estudos sobre a Mudança Socioeconómica e o Território ISCTE-IUL - Av. das Forças Armadas, 1649-026 Lisboa, PORTUGAL 
Therefore, we estimated our investment equation using the Driscoll and Kraay estimator. We identified financial payments as a negative determinant of real investment in EU countries, in accordance with the predictions of the literature on financialisation. Both interest and dividend payments negatively influence real investment. Nevertheless, financial receipts of dividends exert a positive impact on real investment, in contradiction with the literature on financialisation. This seems to illustrate that NFCs in EU countries are using financial incomes to fund real investments, which excludes the "crowding effect". We also conclude that the prejudicial effects of the financialisation on real investment are worse in the more financialised countries. This reveals that there is a tendency for the investment rate of a country to be (inversely) related with the degree of financialisation. Future research should extend the analysis to sustain the validity of this assumption, namely through the use of other broader and more complex indicators to distinguish between more and less financialised countries. We also find that debt exerts a negative influence on real investment, which suggests that the NFCs' indebtedness reaches unsafe levels by limiting the possibility to obtain further funding to finance productive investments. Another possible extension of this work is the use of different measures to capture the two channels of financialisation. The proportion of financial assets to total assets of NFCs and the level of payout ratios of NFCs appear to be two interesting alternatives.

The use of an aggregate investment function to assess the behaviour of NFCs, which is supported by microeconomic fundaments, has the advantage of understanding if the financialisation process has prejudicial macroeconomic effects in EU countries. However, this approach introduces some limitations on the respective analysis, since we are unable to identify whether these prejudicial effects are due to the impact of some corporations/countries or a generalised phenomenon across the majority of corporations from different sectors/industries/countries and with different dimension and ownership. It would be interesting to extend this work using micro databases at a corporation-level or industry-level.

Our findings suggest that the prejudicial effects of financialisation on real investment are not peculiar to the most developed and financialised economies, such as USA and UK. Instead, it seems to be a generalised phenomenon that negatively affects most EU countries, albeit with different intensities in accordance with the level of financialisation.

DINÂMIA'CET - IUL, Centro de Estudos sobre a Mudança Socioeconómica e o Território ISCTE-IUL - Av. das Forças Armadas, 1649-026 Lisboa, PORTUGAL 
Financialisation and real investment in the European Union using a country-level analysis: beneficial or prejudicial effects?

\section{REFERENCES}

AGLIETTA, M. (2000), "Shareholder Value and Corporate Governance: Some Tricky Questions", Economy and Society, 29 (1), 146-159.

AGLIETTA, M. and BRETON, R. (2001), "Financial Systems, Corporate Control and Capital Accumulation”, Economy and Society, 30 (4), 433-466.

AKKEMIK, K. A. and ÖZEN, Ş. (2014), "Macroeconomic and institutional determinants of financialisation of non-financial firms: Case study of Turkey", Socio-Economic Review, 12 (1), 71-98.

ANG, J. B. (2008), "A Survey of Recent Developments in the Literature of Finance and Growth", Journal of Economic Surveys, 22 (3), 536-576.

ARESTIS, P.; CHORTAREAS, G.; and MAGKONIS, G. (2015), “The Financial Development and Growth Nexus: A Meta-Analysis", Journal of Economic Surveys, 29 (3), 549-565.

ASPARA, J.; PAJUNEN, K.; TIKKANEN, H.; and TAINIO, R. (2014), "Explaining corporate short-termism: self-reinforcing processes and biases among investors, the media and corporate managers", Socio-Economic Review, 12 (4), 667-693.

BAUD, C. and DURAND, C. (2012), "Financialization, globalization and the making of profits by leading retailers", Socio-Economic Review, 10 (2), 241-266.

BALTAGI, B. H. (2005), Econometric Analysis of Panel Data, $3^{\text {rd }}$ Edition, New York, John Wiley \& Sons, Ltd.

BARRADAS, R. and LAGOA, S. (2014), "Financialisation and The Portuguese Real Investment: A Supportive or a Disruptive Relationship?", Working Paper $n^{o}$ 2014/06, DINÂMIA'CET-IUL, ISCTE-IUL.

DINÂMIA'CET - IUL, Centro de Estudos sobre a Mudança Socioeconómica e o Território ISCTE-IUL - Av. das Forças Armadas, 1649-026 Lisboa, PORTUGAL 
Financialisation and real investment in the European Union using a country-level analysis: beneficial or prejudicial effects?

BECK, N. and KATZ, J. N. (1995), "What to do (and not to do) with time-series cross-section data", American Political Science Review, 89 (1), 634-647.

BREUSCH, T. and PAGAN, A. (1980), "The Lagrange multiplier test and its application to model specification in econometrics", Review of Economic Studies, 47 (1), 239-523.

BROOKS, C. (2008), Introductory Econometrics for Finance, $2^{\text {nd }}$ Edition, New York, Cambridge University Press.

BROWN, M. B. and FORSYTHE, A. B. (1974), "Robust Tests for The Equality of Variances", Journal of the American Statistical Association, 69 (1), 364-367.

CAMERON, A. C. and TRIVEDI, P. K. (2009), Microeconometrics Using Stata, Stata Press, Texas.

CINGOLANI, M. (2013), "Finance Capitalism: A Look at the European Financial Accounts", Panoeconomicus, 3, 249-290.

CORDONNIER, L. and VAN DE VELDE, F. (2014), "The demands of finance and the glass ceiling of profit without investment", Cambridge Journal of Economics, 39 (3), 871-885.

CROTTY, J. R. (1990), “Owner-manager conflict and financial theory of investment stability: a critical assessment of Keynes, Tobin, and Minsky”, Journal of Post Keynesian Economics, 12 (4), 519-542.

CROTTY, J. R. (2005), “The Neoliberal Paradox: The Impact of Destructive Product Market Competition and Impatient Finance on Nonfinancial Corporations in the Neoliberal Era", in Epstein, G. A. (2005), Financialisation and the World Economy, Edward Elgar Publishing Limited, Cheltenhan.

DAVIDSON, P. (2000), “There are major differences between Kalecki's theory of employment and Keynes's general theory of employment interest and money", Journal of Post Keynesian Economics, 23 (1), 3-25.

DINÂMIA'CET - IUL, Centro de Estudos sobre a Mudança Socioeconómica e o Território ISCTE-IUL - Av, das Forças Armadas, 1649-026 Lisboa, PORTUGAL 
Financialisation and real investment in the European Union using a country-level analysis: beneficial or prejudicial effects?

DRISCOLL, J. C. and KRAAY, A. C. (1998), "Consistent Covariance Matrix Estimation with Spatially Dependent Panel Data", Review of Economics and Statistics, 80 (1), 549-560.

DUMÉNIL, G. and LÉVY, D. (2004), Capital Resurgent: Roots of the Neoliberal Revolution, New York, Harvard University Press.

DRUKKER, D. M. (2003), “Testing for Serial Correlation in Linear Panel-Data Models", The Stata Journal, 3 (2), 168-177.

EISNER, R. (1974), "Econometric Studies of Investment Behavior: A Comment", Economic Inquiry, 12 (1), 91-104.

FAZZARI, S. M.; HUBBARD, R. G.; and PETERSEN, B. C. (1988), "Financing Constraints and Corporate Investment", Brookings Papers on Economic Activity, 1, 141-206.

FREES, E. W. (1995), "Assessing Cross-Sectional Correlation in Panel Data", Journal of Econometrics, 69 (2), 393-414.

FREES, E. W. (2004), Longitudinal and Panel Data: Analysis and Applications in The Social Sciences, Cambridge, Cambridge University Press.

FRIEDMAN, M. (1937), "The use of ranks to avoid the assumption of normality implicit in the analysis of variance", Journal of the American Statistical Association, 32 (1), 675-701.

GERTLER, M. and GILCHRIST, G. (1994), "Monetary Policy, Business Cycles, and the Behavior of Small Manufacturing Firms”, Quarterly Journal of Economics, 109 (2), 309-340.

GREEN, W. H. (2000), Econometric Analysis, New York, Prentice-Hall.

HAUSMAN, J. A. (1978), "Specification Tests in Econometrics", Econometrica, 46 (1), 12511271.

HEIN, E. (2012), The Macroeconomics of Finance-dominated Capitalism - and its Crisis, Cheltenham, Edward Elgar Publishing Limited.

DINÂMIA'CET - IUL, Centro de Estudos sobre a Mudança Socioeconómica e o Território ISCTE-IUL - Av, das Forças Armadas, 1649-026 Lisboa, PORTUGAL

Tel. 210464031 - Extensão 293100 E-mail: dinamia@iscte.pt http://dinamiacet.iscte-iul.pt/ 
Financialisation and real investment in the European Union using a country-level analysis: beneficial or prejudicial effects?

HEIN, E. and DODIG, N. (2015), "Finance dominated capitalism, distribution, growth and crisis - long-run tendencies" in HEIN, E; DETZER, D.; and DODIG, N. (2015), The Demise of Finance-dominated Capitalism: Explaining the Financial and Economic Crises, Cheltenham, Edward Elgar Publishing Limited.

HEIN, E. and VAN TREECK, T. (2010), “'Financialisation' in Post-Keynesian models of distribution and growth" in SETTERFIELD, M. (2010), Handbook of Alternative Theories of Economic Growth, Cheltenham, Edward Elgar Publishing Limited.

HLOUSKOVA, J. and WAGNER, M. (2006), "The Performance of Panel Unit Root and Stationarity Tests: Results from a Large Scale Simulation Study”, Econometric Reviews, 25 (1), $85-116$.

HOECHLE, D. (2007), "Robust Standard Errors for Panel Regressions with Cross-Sectional Dependence", The Stata Journal 7 (3), 281-312.

HOYOS, R. E. D. and SARAFIDIS, V. (2006), "Testing for cross-sectional dependence in panel-data models", The Stata Journal, 6 (4), 482-496.

KOPCKE, R. and BRAUMAN, R. (2001), "The Performance of Traditional Macroeconomic Models of Businesses' Investment Spending”, New England Economic Review, 2 (1), 3-39.

KRIPPNER, G. R. (2005), "The Financialisation of the American Economy”, Socio-Economic Review, 3 (2), 173-208.

KUH, E. and MEYER, J. (1955), "Acceleration and Related Theories of Investment: An Empirical Inquiry", Review of Economics and Statistics, 38 (3), 217-230.

LAZONICK, W. and O'SULLIVAN, M. (2000), "Maximising shareholder value: a new ideology for corporate governance", Economic and Society, 29 (1), 13-35.

LEVENE, H. (1960), "Robust Tests for The Equality of Variances" in OLKIN, I.; GHURYE, S. G.; HOEFFDING, W.; MADOW, W. G.; and MANN, H. B. (eds.) (1960), Contributions to 
Financialisation and real investment in the European Union using a country-level analysis: beneficial or prejudicial effects?

Probability and Statistics: Essays in Honor of Harold Hotelling, Stanford, Stanford University Press.

LEVINE, R. (2005), "Finance and Growth: Theory and Evidence" in AGHION, P. and DURLAUF, S. N. (eds.) (2005), Handbook of Economic Growth, Amsterdam, Elsevier.

LEVY-ORLIK, N. (2012), "Effects of financialisation on the structure of production and nonfinancial private enterprises: the case of Mexico", Journal of Post Keynesian Economics, 35 (2), 235-254.

LIN, K. and TOMASKOVIC-DEVEY, D. (2013), "Financialisation and US Income Inequality, 1970 - 2008”, American Journal of Sociology, 118 (5), 1284-1329.

LOPES, A. F. (2003), “Os ciclos económicos nos países pertencentes à União Europeia: Breve comparação do comportamento cíclico dos estados membros", Working Paper $n^{\circ} 35$, DINÂMIA'CET-IUL, ISCTE-IUL.

MINSKY, H. (1975), John Mayard Keynes, New York, Columbia University Press.

NDIKUMANA, L. (1999), "Debt Service, Financing Constraints, and Fixed Investment: Evidence from Panel Data", Journal of Post Keynesian Economics, 21 (3), 455-478.

ONARAM, Ö.; STOCKHAMMER, E.; GRAFL, L. (2011), "Financialisation, income distribution and aggregate demand in the USA", Cambridge Journal of Economics, 35 (4), 637 661.

ORHANGAZI, Ö. (2008a), Financialization and the US Economy, Cheltenham, Edward Elgar Publishing Limited.

ORHANGAZI, Ö. (2008b), "Financialisation and capital accumulation in the non-financial corporate sector: A theoretical and empirical investigation on the US economy: 1973-2003", Cambridge Journal of Economics, 32 (6), 863-886.

DINÂMIA'CET - IUL, Centro de Estudos sobre a Mudança Socioeconómica e o Território ISCTE-IUL - Av. das Forças Armadas, 1649-026 Lisboa, PORTUGAL 
Financialisation and real investment in the European Union using a country-level analysis: beneficial or prejudicial effects?

PARKS, R. (1967), "Efficient Estimation of a System of Regression Equations When Disturbances Are Both Serially and Contemporaneously Correlated", Journal of the American Statistical Association, 62 (1), 500-509.

PESARAN, M. H. (2004), "General diagnostic tests for cross section dependence in panels", Cambridge Working Papers in Economics $n^{\circ} 0435$, University of Cambridge.

REED, W. R. and YE, H. (2011), "Which panel data estimator should I use?", Applied Economics, 43 (1), 985-1000.

SAMUEL, C. (2000), "Does Shareholder Myopia Lead to Managerial Myopia? A First Look", Applied Financial Economics, 10 (5), 493-505.

SAWYER, M. (2013), "Bank-based versus market-based financial systems: a critique of the dichotomy”, FESSUD Working Paper Series n $n^{\circ}$ 19, FESSUD Project.

SOENER, M. C. (2015), "Why do firms financialize? Meso-level evidence from the US apparel and footwear industry, 1991-2005", Socio-Economic Review, forthcoming.

SØRENSEN, P. B. and WHITTA-JACOBSEN, H. J., Introducing Advanced Macroeconomics: Growth \& Business Cycles, Maidenhead, McGraw-Hill.

STOCKHAMMER, E. (2004), "Financialisation and the slowdown of accumulation", Cambridge Journal of Economics, 28 (5), 719-741.

STOCKHAMMER, E. (2010), "Financialization and the Global Economy", Working Paper $n^{o}$ 240, Political Economy Research Institute, Washington.

STUDENMUND, A. H. (2005), Using Econometrics: A Practical Guide, $5^{\text {th }}$ Edition, Boston, Addison Wesley Pearson

TOBIN, J. (1965), “Money and Economic Growth”, Econometrica, 33 (4), 671-684.

DINÂMIA'CET - IUL, Centro de Estudos sobre a Mudança Socioeconómica e o Território ISCTE-IUL - Av, das Forças Armadas, 1649-026 Lisboa, PORTUGAL Tel. 210464031 - Extensão 293100 E-mail: dinamia@iscte.pt http://dinamiacet.iscte-iul.pt/ 
Financialisation and real investment in the European Union using a country-level analysis: beneficial or prejudicial effects?

TOMASKOVIC-DEVEY, D.; LIN, K.; and MEYERS, N. (2015), "Did financialisation reduce economic growth?", Socio-Economic Review, forthcoming.

VAN DER ZWAN, N. (2014), "Making sense of financialisation”, Socio-Economic Review, 12 (1), 99-129.

VAN TREECK, T. (2008), "Reconsidering the Investment-Profit Nexus in Finance-Led Economies: an ARDL-Based Approach”, Metroeconomica, 59 (3), 371-404.

WOOLDRIDGE, J. M. (2002), Econometric Analysis of Cross Section and Panel Data, Cambridge, The MIT Press. 
Financialisation and real investment in the European Union using a country-level analysis: beneficial or prejudicial effects?

\section{APPENDIX}

Table A1 - The descriptive statistics of the data

\begin{tabular}{c|cccccccc}
\hline & $\boldsymbol{I}$ & $\boldsymbol{P}$ & $\boldsymbol{D}$ & $\boldsymbol{C C}$ & $\boldsymbol{S R}$ & $\boldsymbol{O G}$ & $\boldsymbol{F R}$ & $\boldsymbol{F P}$ \\
\hline Observations & 450 & 450 & 450 & 450 & 450 & 450 & 450 & 450 \\
Mean & 0.246 & 0.427 & -0.019 & 0.026 & 0.096 & 0.025 & 0.090 & 0.212 \\
Median & 0.238 & 0.414 & -0.013 & 0.025 & 0.105 & 0.028 & 0.066 & 0.205 \\
Maximum & 0.512 & 0.603 & 0.250 & 0.245 & 0.211 & 0.140 & 0.637 & 0.708 \\
Minimum & 0.041 & 0.280 & -0.447 & -0.232 & -0.202 & -0.150 & 0.001 & 0.043 \\
Standard Deviation & 0.070 & 0.074 & 0.092 & 0.039 & 0.066 & 0.036 & 0.083 & 0.091 \\
Skewness & 0.769 & 0.278 & -0.502 & 0.325 & -1.282 & -0.907 & 2.509 & 1.264 \\
Kurtosis & 3.516 & 2.274 & 4.467 & 13.413 & 5.090 & 6.662 & 12.715 & 6.708 \\
\hline
\end{tabular}

Figure A1 - The plots of investment (\% of gross value added)
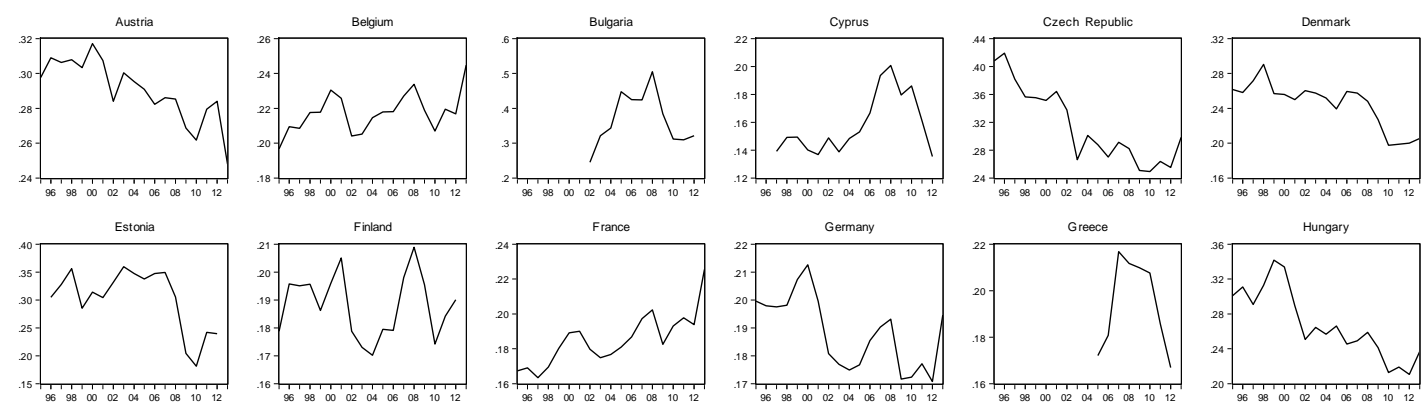

France

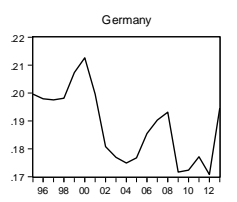

Greece
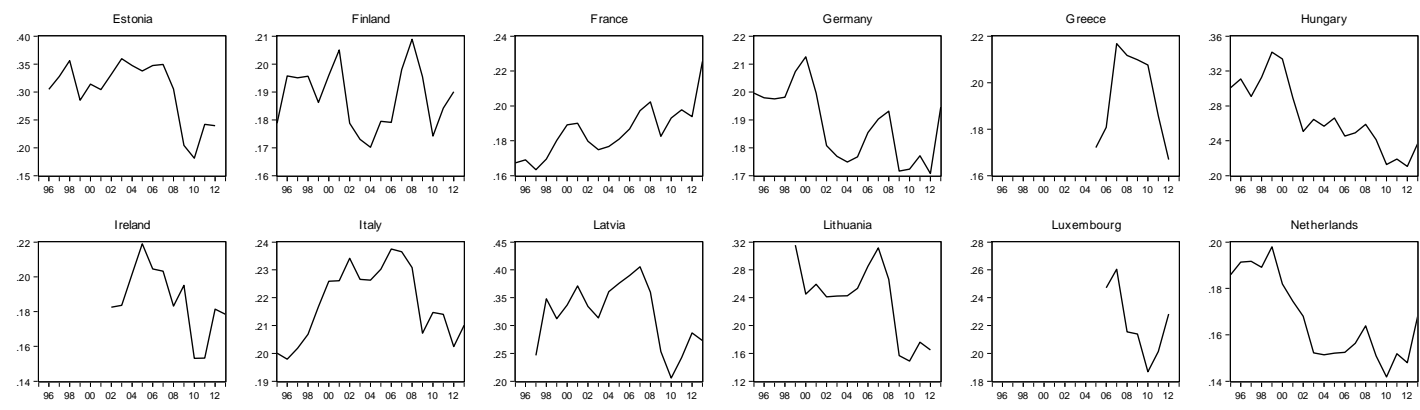

Latvia
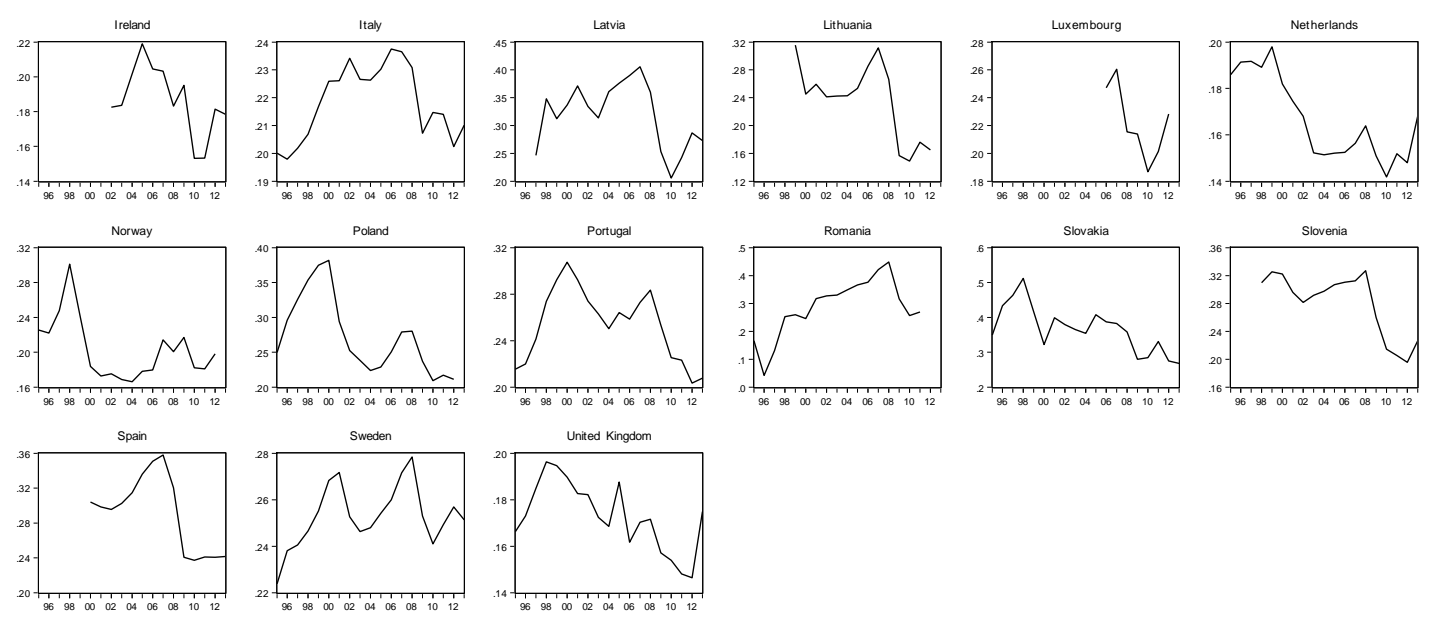

DINÂMIA'CET - IUL, Centro de Estudos sobre a Mudança Socioeconómica e o Território ISCTE-IUL - Av. das Forças Armadas, 1649-026 Lisboa, PORTUGAL

Tel. 210464031 - Extensão 293100 E-mail: dinamia@iscte.pt http://dinamiacet.iscte-iul.pt/ 
Financialisation and real investment in the European Union using a country-level analysis: beneficial or prejudicial effects?

Figure A2 - The plots of profitability (\% of gross value added)
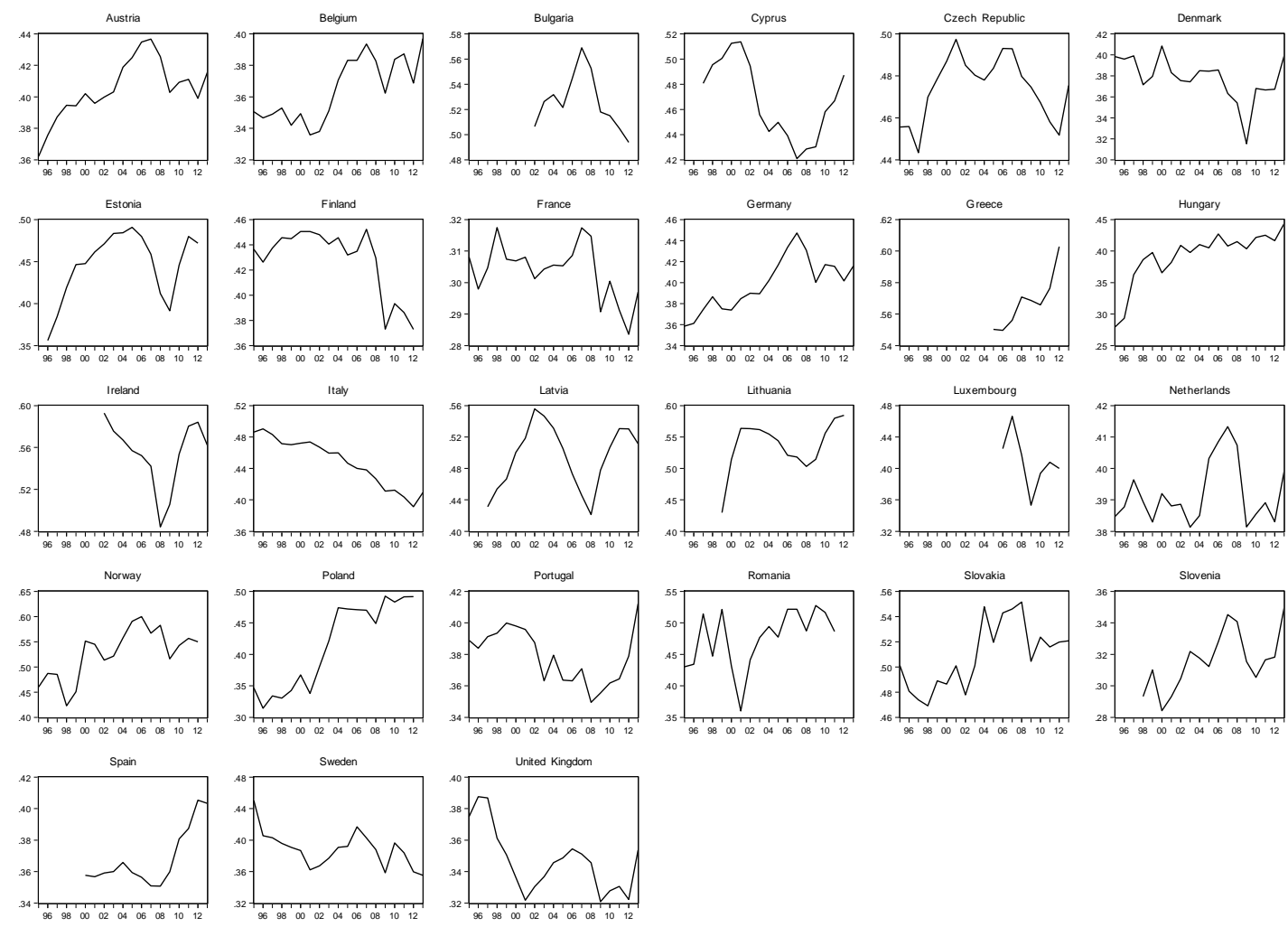

Figure A3 - The plots of debt (\% of gross value added)
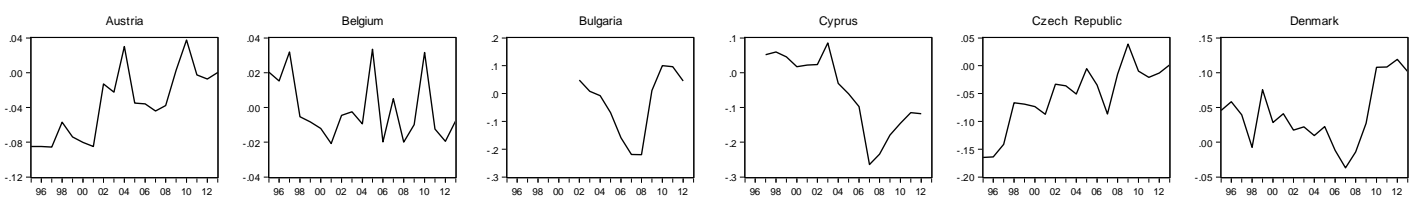

Estonia

France
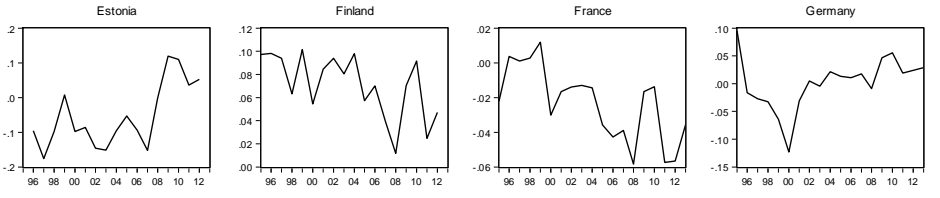

Greece
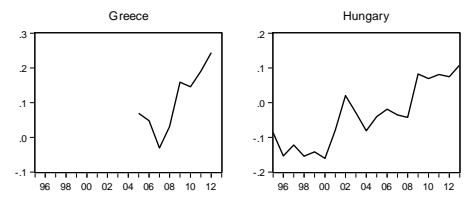

Latvia

Lithuania
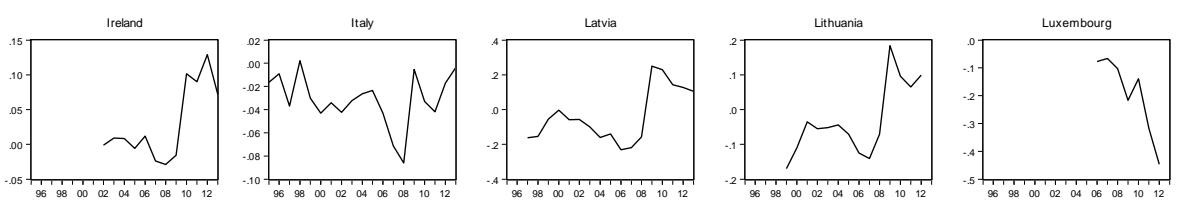

Netherlands

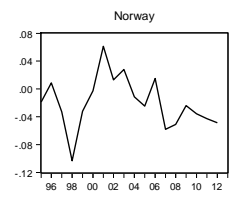

Polan

Portugal
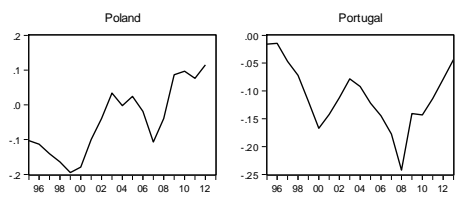

Romania

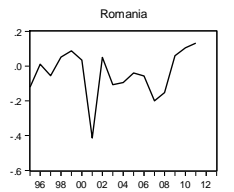

Slovakia

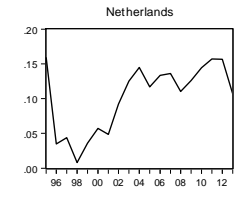

Spain

Sweden
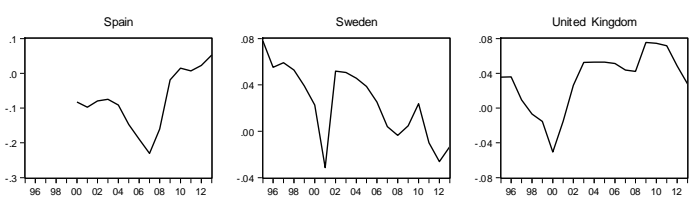

Slovenia

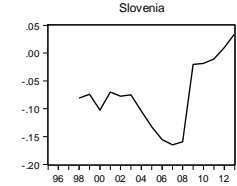


Financialisation and real investment in the European Union using a country-level analysis: beneficial or prejudicial effects?

Figure A4 - The plots of cost of capital (\%)
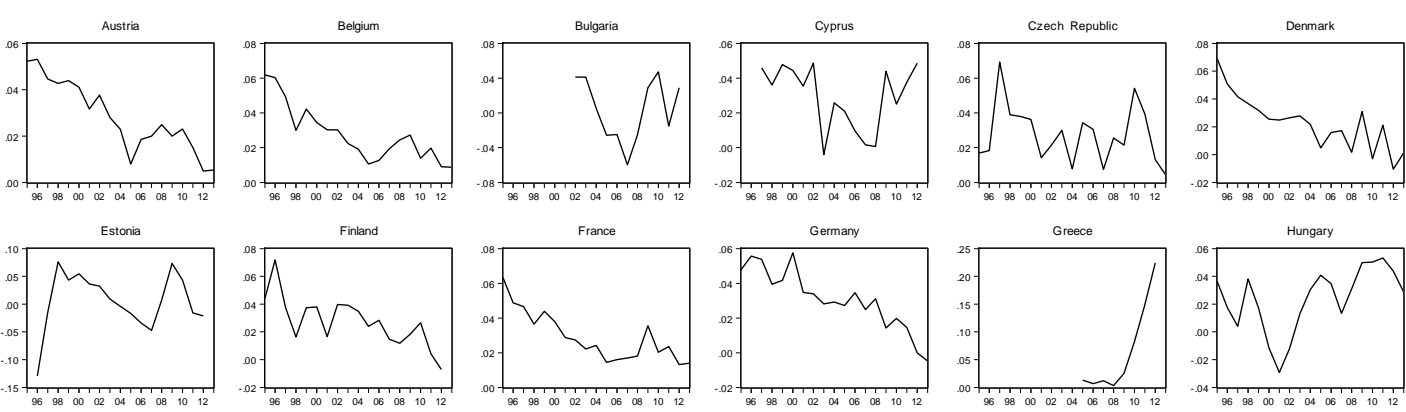

France
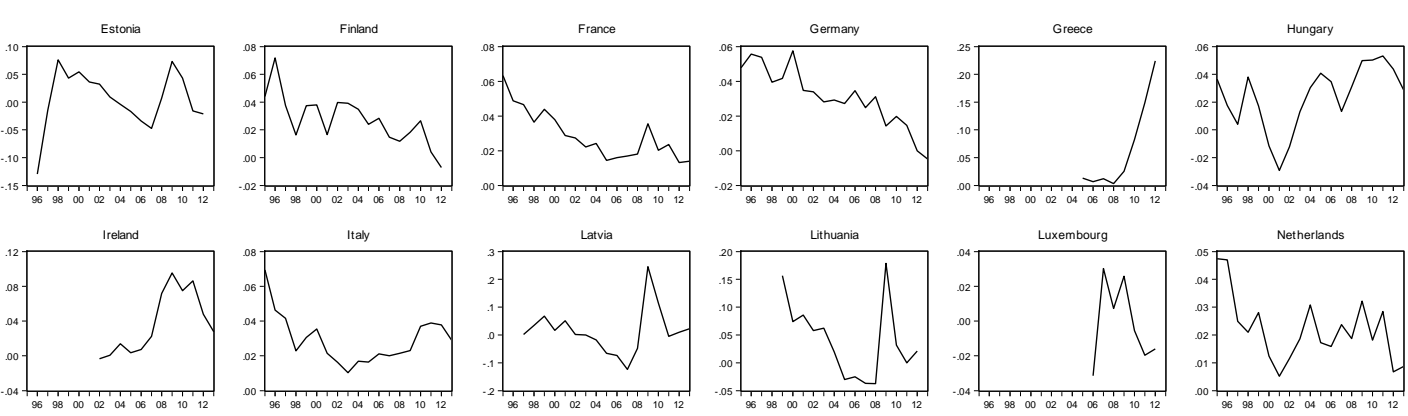

Italy

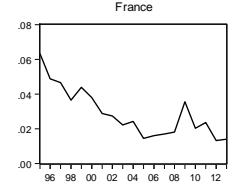

Lithuania
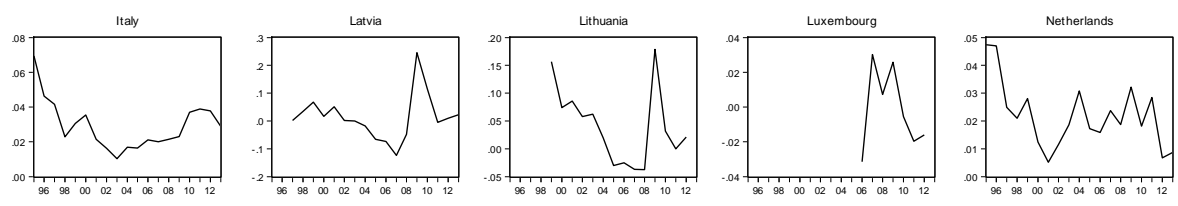

Poland

Portugal

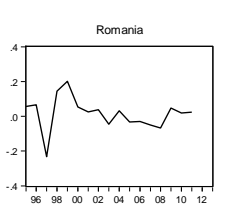

Slovakia
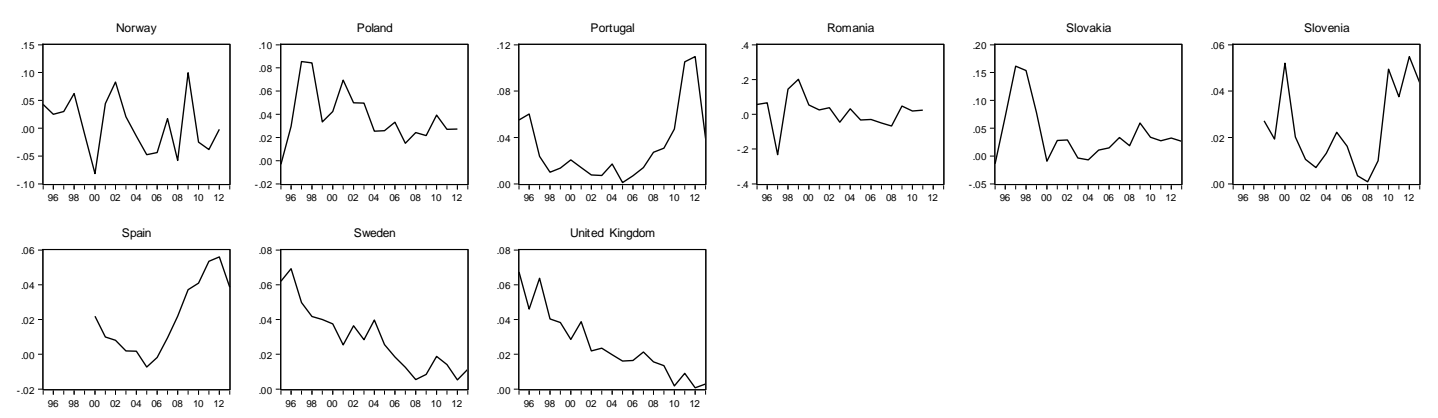

Figure A5 - The plots of savings rate (\% of disposable income)
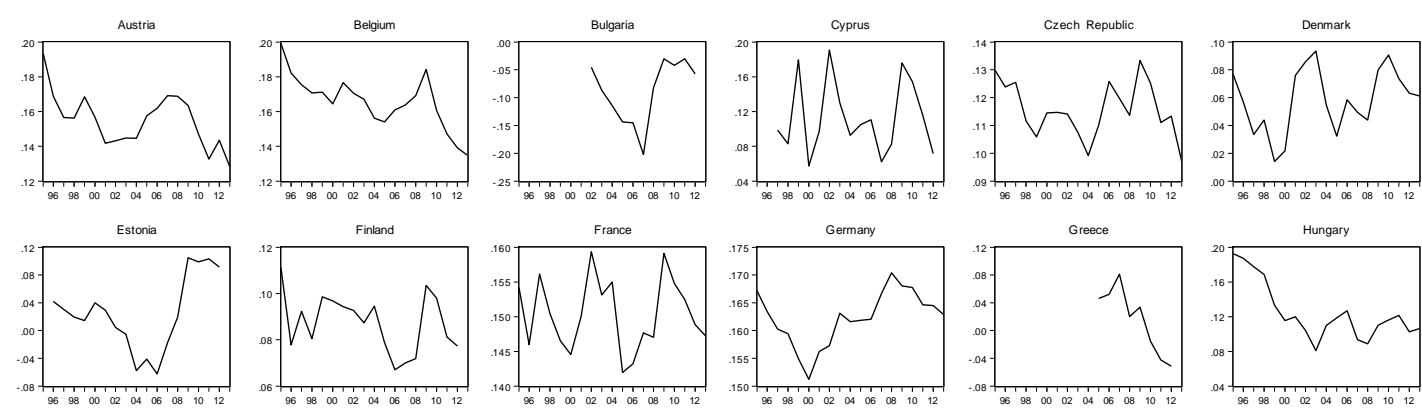

Ireland

Italy

Latvia
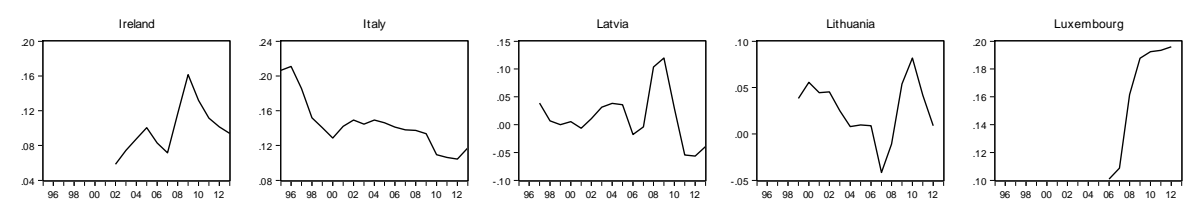

Netherlands

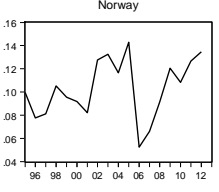

Poland

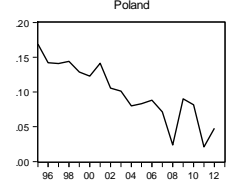

Portugal
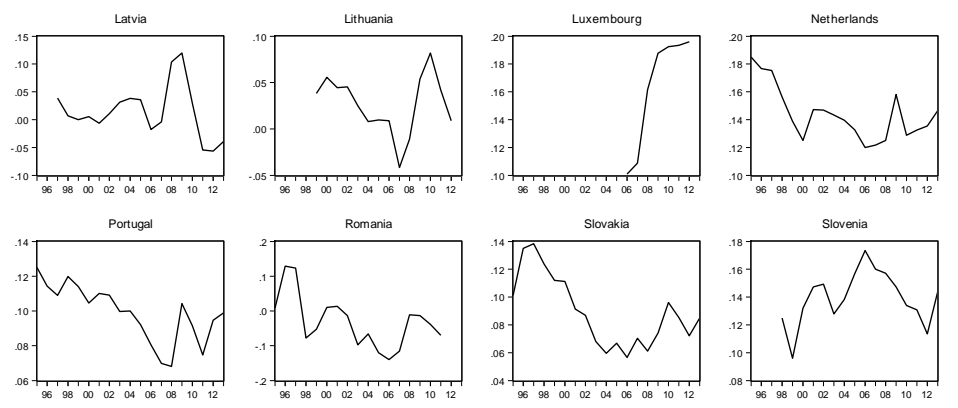

Sweden
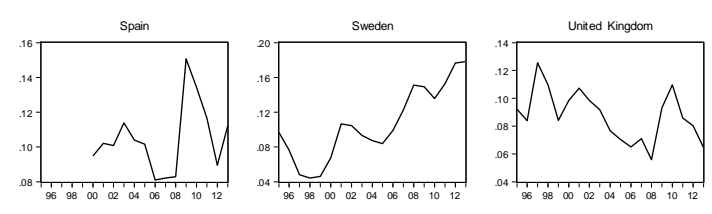

DINÂMIA'CET - IUL, Centro de Estudos sobre a Mudança Socioeconómica e o Território

ISCTE-IUL - Av. das Forças Armadas, 1649-026 Lisboa, PORTUGAL

Tel. 210464031 - Extensão 293100 E-mail: dinamia@iscte.pt http://dinamiacet.iscte-iul.pt/ 
Financialisation and real investment in the European Union using a country-level analysis: beneficial or prejudicial effects?

Figure A6 - The plots of output growth (annual growth rate)
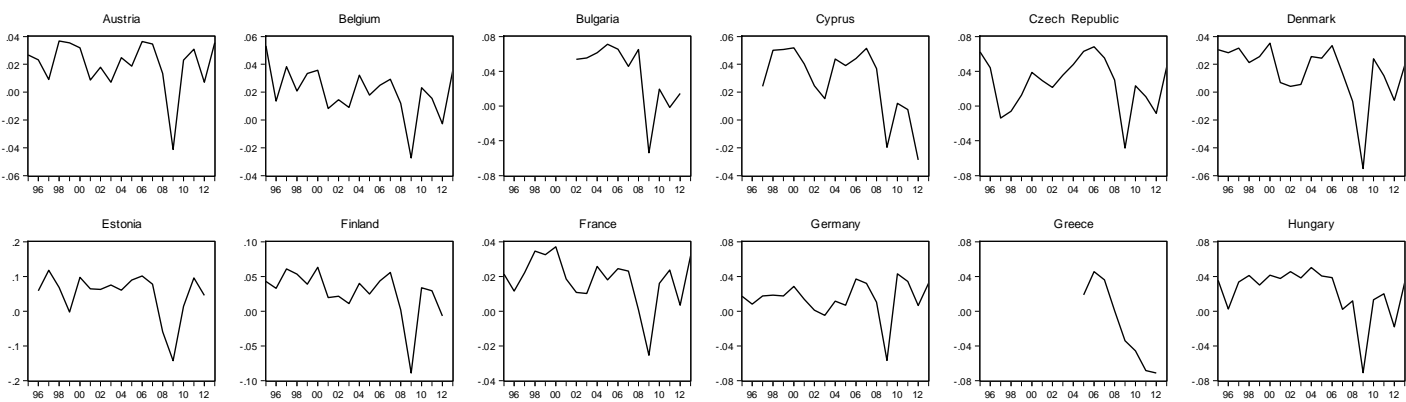

Finlar

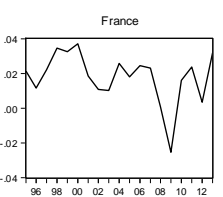

German

Greece

Latvia
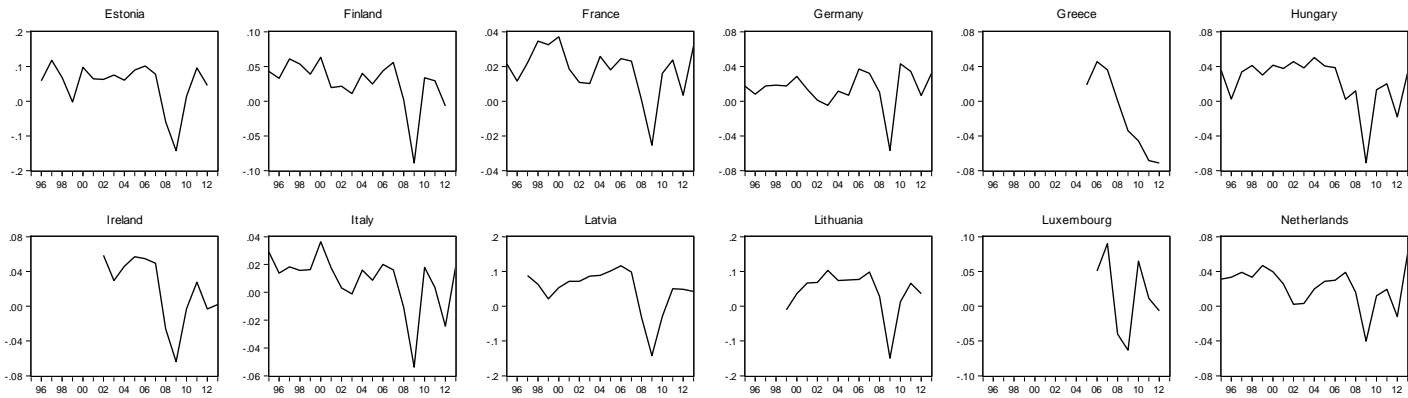

Lithuaria
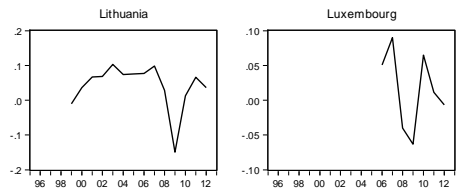

Netherlands

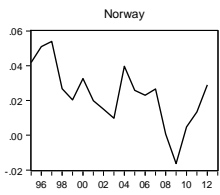

Poland

Portugal

Romania
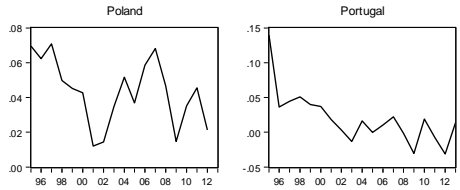

Slovakia
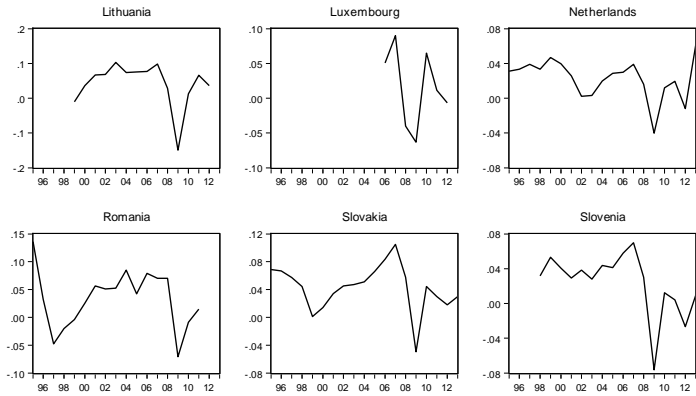

Sweden
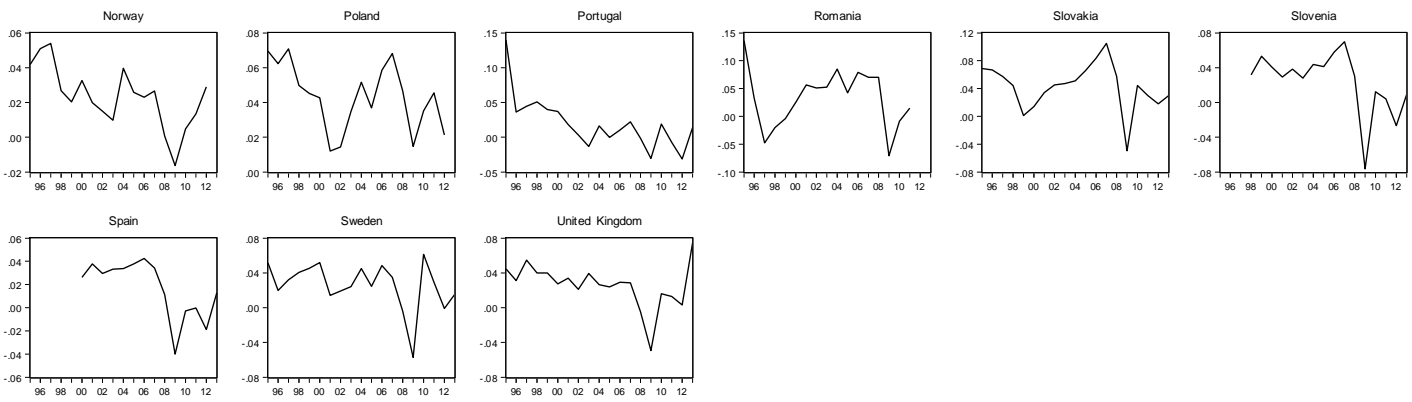

Figure A7 - The plots of financial receipts (\% of gross value added)
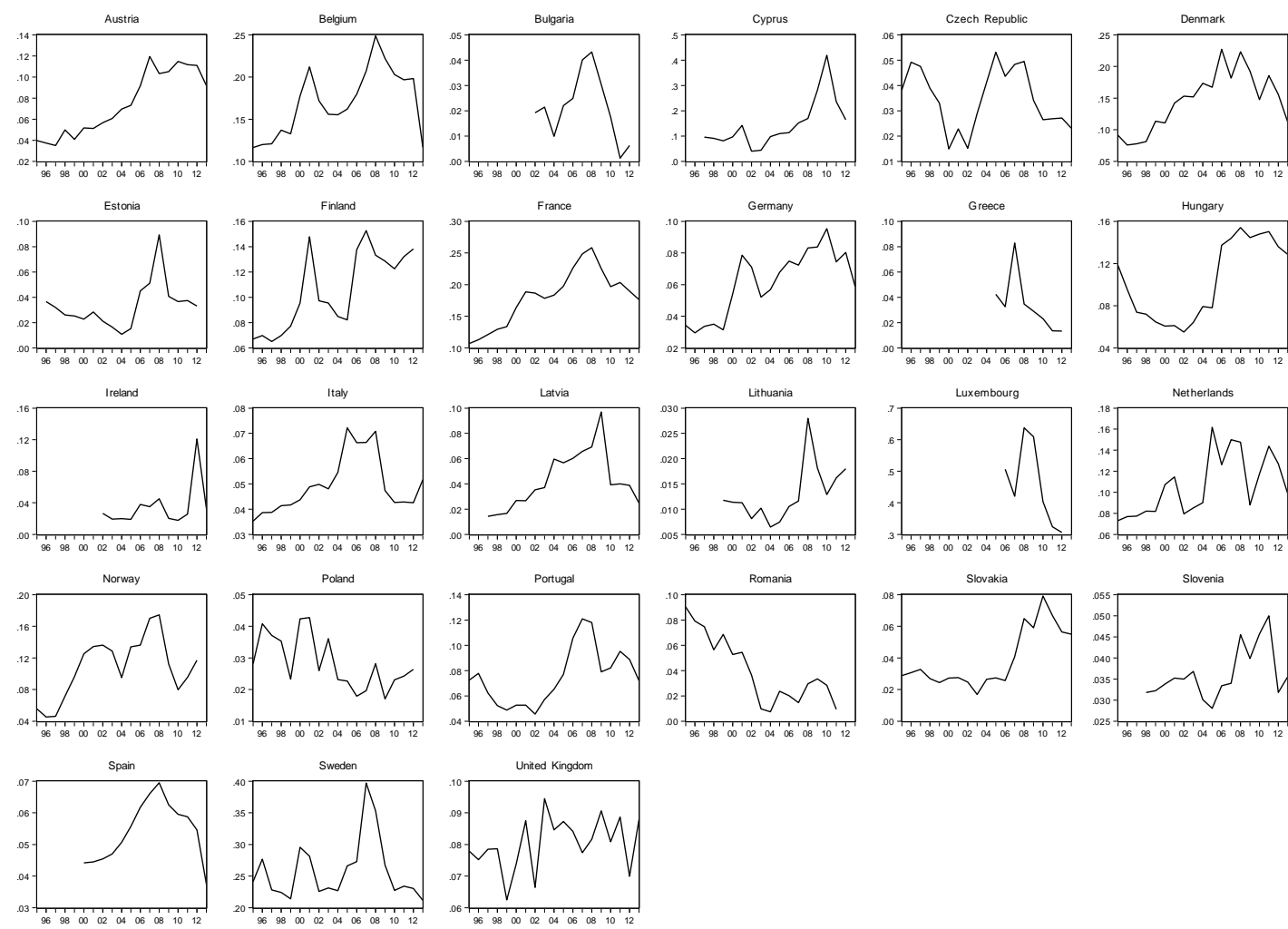

DINÂMIA'CET - IUL, Centro de Estudos sobre a Mudança Socioeconómica e o Território ISCTE-IUL - Av, das Forcas Armadas, 1649-026 Lisboa, PORTUGAL

Tel. 210464031 - Extensão 293100 E-mail: dinamia@iscte.pt http://dinamiacet.iscte-iul.pt/ 
Financialisation and real investment in the European Union using a country-level analysis: beneficial or prejudicial effects?

Figure A8 - The plots of financial payments (\% of gross value added)
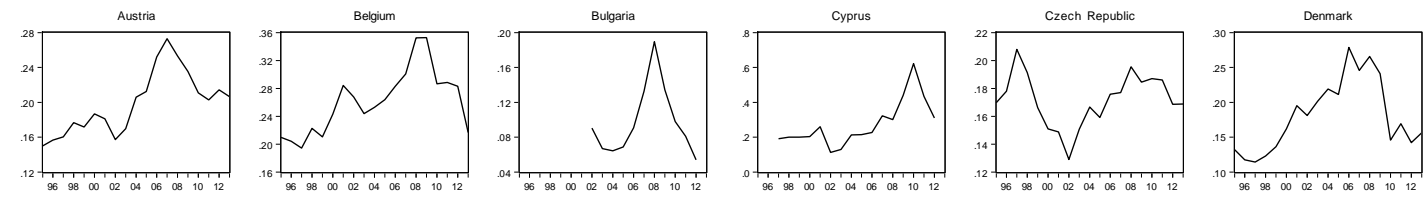

Estonia

Finland

France
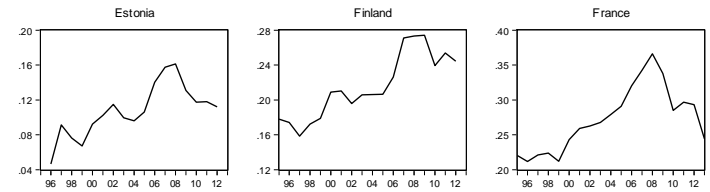

Germany

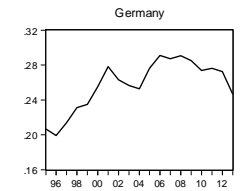

Greece
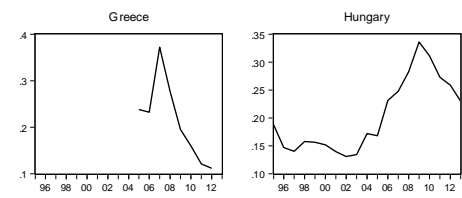

Latvia

Lithuania

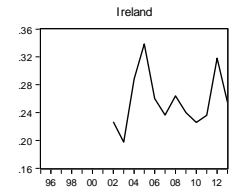

Italy
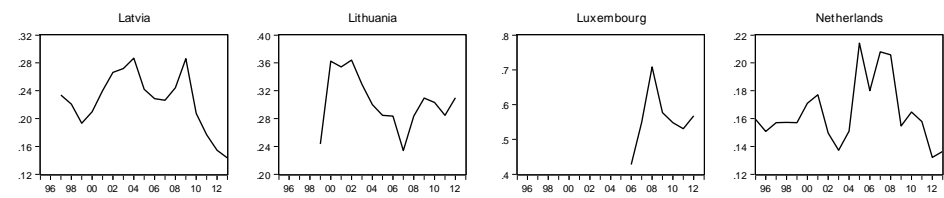

Norway

Poland

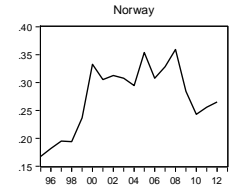

Portugal
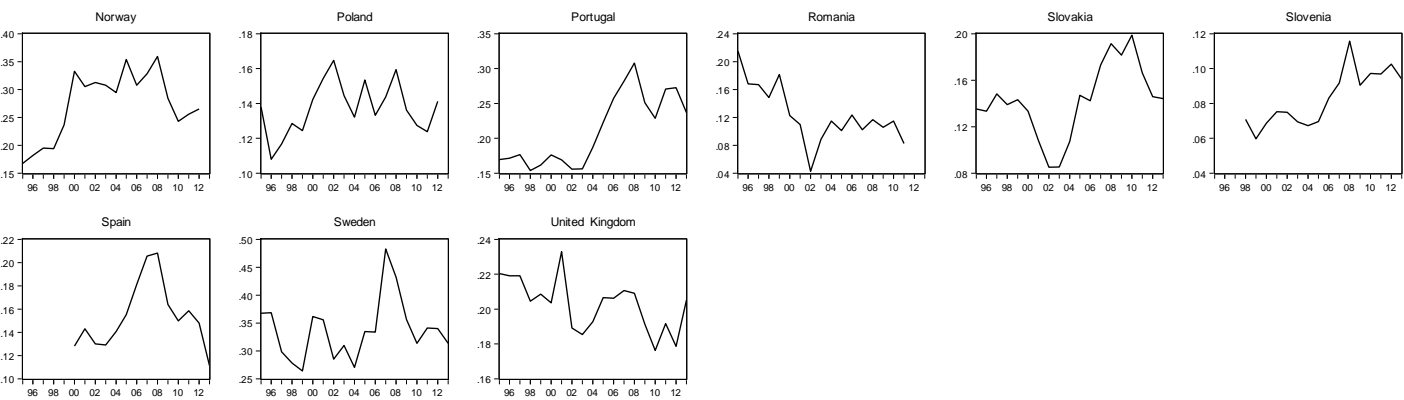

Sweden
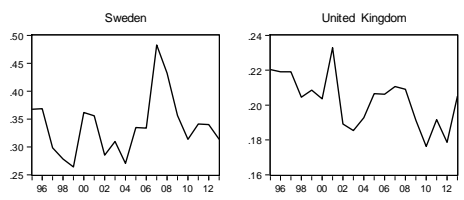

Table A2 - The Breusch and Pagan Lagrangian Multiplier (LM) test and the Hausman test for the investment function with financial receipts and financial payments divided between interest and dividends

\begin{tabular}{c|c|c}
\hline Test & Chi-square & P-value \\
\hline LM test & 931.08 & 0.000 \\
Hausman test & 6.42 & 0.697 \\
\hline
\end{tabular}

Table A3 - Diagnostic tests for the investment function with financial receipts and financial payments divided between interest and dividends

\begin{tabular}{|c|c|c|c|}
\hline \multicolumn{2}{|c|}{ Test } & Statistic & $P$-value \\
\hline \multirow{3}{*}{$\begin{array}{c}\text { Period } \\
\text { Heteroscedasticity }\end{array}$} & $\mathrm{W}_{0}$ & 2.743 & 0.000 \\
\hline & $\mathrm{W}_{\mathbf{5 0}}$ & 2.170 & 0.005 \\
\hline & $W_{10}$ & 2.549 & 0.001 \\
\hline \multirow{3}{*}{$\begin{array}{c}\text { Cross-sectional } \\
\text { Heteroscedasticity }\end{array}$} & $\mathrm{W}_{0}$ & 7.748 & 0.000 \\
\hline & $W_{50}$ & 5.412 & 0.000 \\
\hline & $\mathbf{W}_{10}$ & 7.102 & 0.000 \\
\hline \multicolumn{2}{|c|}{$\begin{array}{l}\text { Group-wise Heteroscedasticity } \\
\text { Serial Correlation }\end{array}$} & $\begin{array}{l}\text { n. a. } \\
46.357\end{array}$ & $\begin{array}{l}\text { n. a. } \\
0.000\end{array}$ \\
\hline & Friedman & 24.741 & 0.534 \\
\hline $\begin{array}{l}\text { Cross-sectional } \\
\text { Dependence }\end{array}$ & Frees & 1.552 & n. a. \\
\hline
\end{tabular}

Note: The critical values from Frees' Q distribution (T-asymptotically distributed) are 0.489, 0.686 and 1.105 to the significance levels of $10 \%, 5 \%$ and $1 \%$, respectively.

DINÂMIA'CET - IUL, Centro de Estudos sobre a Mudança Socioeconómica e o Território ISCTE-IUL - Av. das Forças Armadas, 1649-026 Lisboa, PORTUGAL

Tel. 210464031 - Extensão 293100 E-mail: dinamia@iscte.pt http://dinamiacet.iscte-iul.pt/ 
Financialisation and real investment in the European Union using a country-level analysis: beneficial or prejudicial effects?

Table A4 - The Wald test on the equality of interest payments and dividends payments

\begin{tabular}{c|cc}
\hline Null hypothesis & T-statistic & $P$-value \\
\hline $\boldsymbol{I P}$ & 0.09 & 0.773 \\
\hline
\end{tabular}

Table A5 - The average of financial receipts and financial payments per country

\begin{tabular}{|c|c|c|}
\hline Country & FR & FP \\
\hline Austria & 0.074 & 0.199 \\
\hline Belgium & 0.170 & 0.261 \\
\hline Bulgaria & 0.021 & 0.097 \\
\hline Cyprus & 0.146 & 0.274 \\
\hline Czech Republic & 0.035 & 0.172 \\
\hline Denmark & 0.145 & 0.181 \\
\hline Estonia & 0.033 & 0.108 \\
\hline Finland & 0.105 & 0.215 \\
\hline France & 0.180 & 0.272 \\
\hline Germany & 0.061 & 0.257 \\
\hline Greece & 0.034 & 0.213 \\
\hline Hungary & 0.103 & 0.203 \\
\hline Ireland & 0.035 & 0.257 \\
\hline Italy & 0.050 & 0.278 \\
\hline Latvia & 0.047 & 0.225 \\
\hline Lithuania & 0.013 & 0.303 \\
\hline Luxembourg & 0.458 & 0.558 \\
\hline Netherlands & 0.107 & 0.164 \\
\hline Norway & 0.108 & 0.273 \\
\hline Poland & 0.029 & 0.137 \\
\hline Portugal & 0.075 & 0.211 \\
\hline Romania & 0.041 & 0.124 \\
\hline Slovakia & 0.039 & 0.142 \\
\hline Slovenia & 0.036 & 0.083 \\
\hline Spain & 0.054 & 0.154 \\
\hline Sweden & 0.258 & 0.337 \\
\hline United Kingdom & 0.080 & 0.203 \\
\hline All Countries & 0.090 & 0.212 \\
\hline
\end{tabular}

Table A6 - The distribution between the more and the less financialised countries

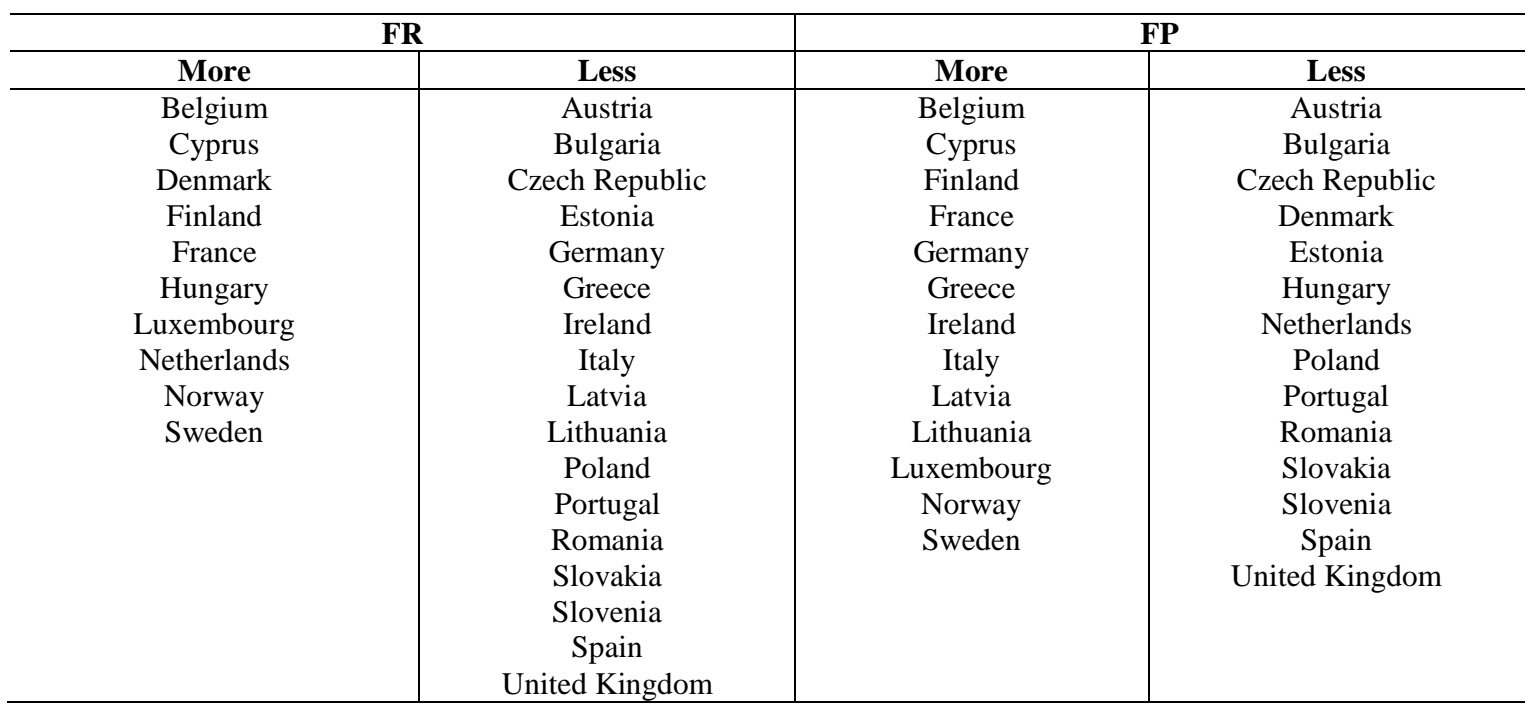

DINÂMIA'CET - IUL, Centro de Estudos sobre a Mudança Socioeconómica e o Território ISCTE-IUL - Av. das Forças Armadas, 1649-026 Lisboa, PORTUGAL

Tel. 210464031 - Extensão 293100 E-mail: dinamia@iscte.pt http://dinamiacet.iscte-iul.pt/ 
Financialisation and real investment in the European Union using a country-level analysis: beneficial or prejudicial effects?

Table A7 - The Breusch and Pagan Lagrangian Multiplier (LM) test and the Hausman test for the investment function with two dummies for the more financialised countries

\begin{tabular}{c|c|c}
\hline Test & Chi-square & P-value \\
\hline LM test & 936.65 & 0.000 \\
Hausman test & 40.44 & 0.000 \\
\hline
\end{tabular}

Table A8 - Diagnostic tests for the investment function with two dummies for the more financialised countries

\begin{tabular}{|c|c|c|c|}
\hline \multicolumn{2}{|c|}{ Test } & Statistic & $P$-value \\
\hline \multirow{3}{*}{$\begin{array}{c}\text { Period } \\
\text { Heteroscedasticity }\end{array}$} & $\mathbf{W}_{0}$ & 1.619 & 0.056 \\
\hline & $\mathbf{W}_{50}$ & 1.550 & 0.074 \\
\hline & $\mathbf{W}_{10}$ & 1.606 & 0.059 \\
\hline \multirow{3}{*}{$\begin{array}{l}\text { Cross-sectional } \\
\text { Heteroscedasticity }\end{array}$} & $\mathbf{W}_{\mathbf{0}}$ & 9.559 & 0.000 \\
\hline & $\mathbf{W}_{50}$ & 5.582 & 0.000 \\
\hline & $W_{10}$ & 8.582 & 0.000 \\
\hline \multicolumn{2}{|c|}{ Group-wise Heteroscedasticity } & 446.38 & 0.000 \\
\hline \multicolumn{2}{|c|}{ Serial Correlation } & 44.617 & 0.000 \\
\hline & Friedman & 33.593 & 0.146 \\
\hline Dependence & Frees & 1.609 & n. a. \\
\hline & Pesaran & 8.584 & 0.000 \\
\hline
\end{tabular}

Note: The critical values from Frees' Q distribution (T-asymptotically distributed) are $0.489,0.686$ and 1.105 to the significance levels of $10 \%, 5 \%$ and $1 \%$, respectively 